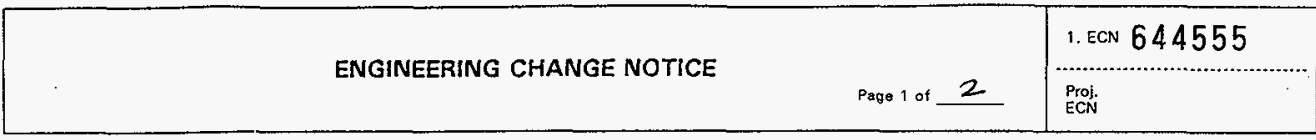

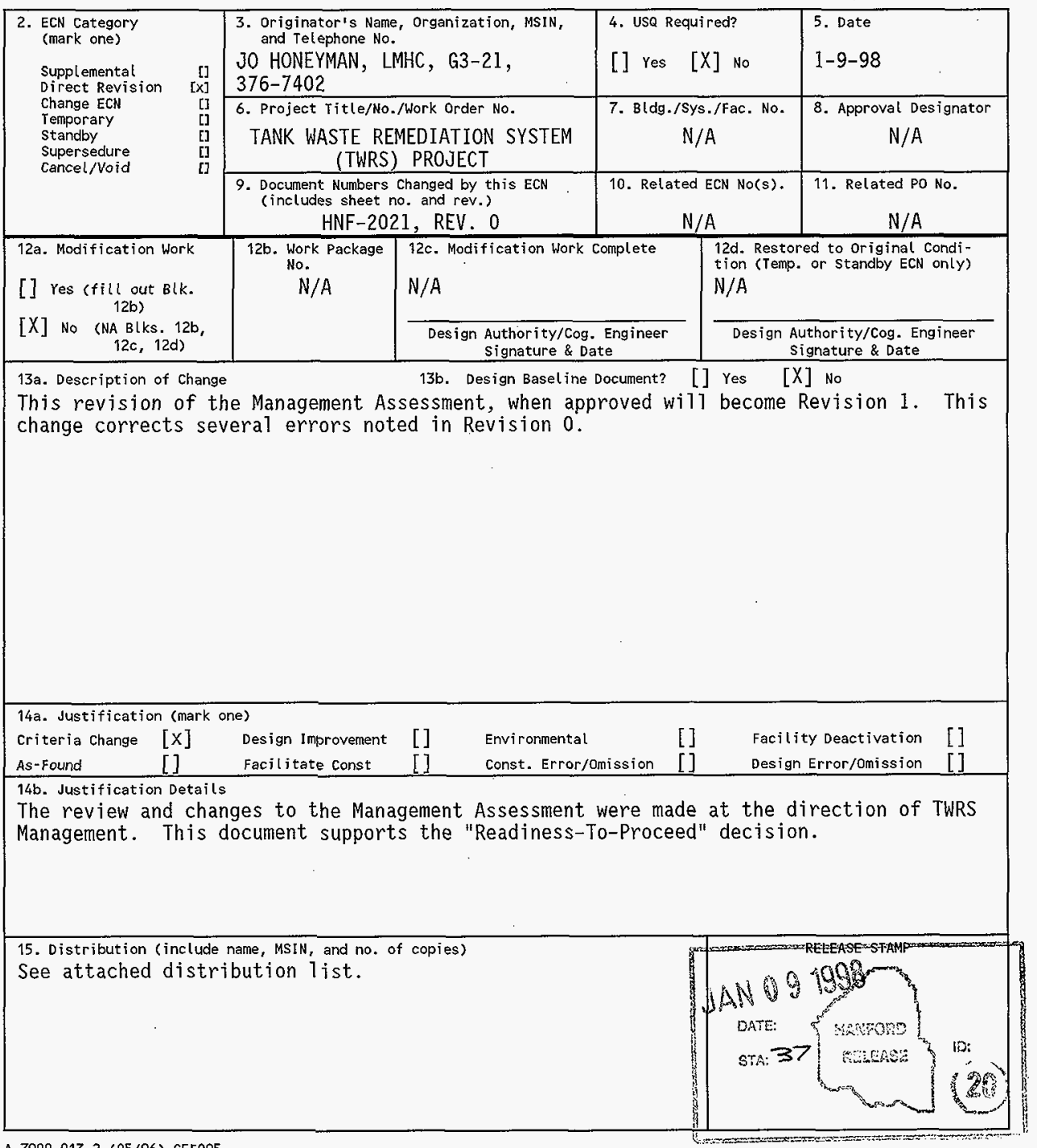




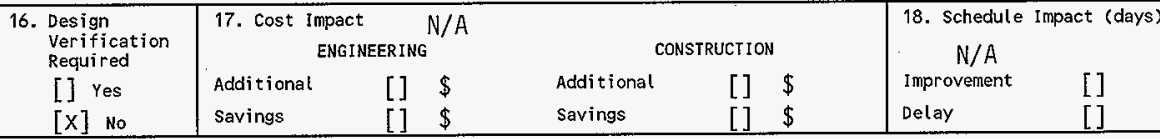

19. Change Impact Review: Indicate the related documents (other than the engineering documents ident ified on side 1 ) that will be affected by the change described in Block 13. Enter the affected document number in Block 20. SDD/DD

Functional Design Criteria

Operating Specification

Criticality Specification

Concoptual Design Report

Equipment Spec.

Const. Spec.

Procurement Spec.

Vendor information

OM Manual

FSAR/SAR

Safety Equipment List

Radiation Work Permit

Environmental Impact Statement

Environmental Report

Environmental Permit

[]
[]
[]
[]
[]
[]
[]
[]
[]
[]
[]
[]
[]
[]
[]
[]

[]

[]

[]

[]

[]

[]

[]

[]

[]

[]

[]

[]

[]

[]

Tank Calibration Manual

Health Physics Procedure

Spares Mustiple Unit Listing

Test Procedures/Specification

Component Index

ASME Coded Item

Human Factor Consideration

Computer Software

Electric Circuit Schedule

ICRS Procedure

Process Control Manual/Plan

Cell Arrangement Drawing

Essential Material Specification

Fac. Proc. Samp. Schedule

Inspection Plan

Inventory Adjustment Request

Process Flow Chart

Purchase Requisition

Tickler File

$N / A$
[]

[]

[]

[]

[]

[]

[]

20. Other Affected Documents: (NOTE: Documents listed below will mot be revised by this ECN.) Signatures below indicate that the signing organization has been notified of other affected documents listed below.

Document Number/Revision

Document Number/Revision

Document Number Revision

\section{N/A}

21. Approvals

Design Authority N/A

Cog. Eng. N/A

Cog. Mgr. N/A

QA N/A

Safety N/A

Environ. N/A

other

Author, M. A. Payne. Mant.

Author's Mgr. L. Hall $(z)$ Hal
Date

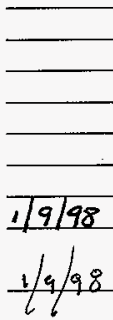

Design Agent $N / A$

PE N/A

QA N/A

Safety N/A

Design N/A

Environ. N/A

other N/A

\section{DEPARTMENT OF ENERGY}

Signature or a Control Number that tracks the Approval Signature

N/A

ADDITIONAL 


\title{
Management Assessment of Tank Waste Remediation System Contractor Readiness To Proceed With Phase 1B Privatization
}

\author{
J.0. Honeyman \\ Lockheed Martin Hanford Company, Richland, WA 99352 \\ U.S. Department of Energy Contract DE-AC06-96RL13200
}

$\begin{array}{lll}\text { EDT/ECN: } & \text { ECN-644555 } & \text { UC: } 2030 \\ \text { Org Code: } & 7 A 200 & \text { Charge Code: D215P } \\ \text { B\&R Code: } & \text { EW3130010 } & \text { Total Pages: } 7975 \text { DPC peA VLB }\end{array}$

Key Words: TWRS, Mission Analysis

Abstract: This Management Assessment documents the process used to determine readiness to proceed with tank waste treatment technologies from private industry, now known as "TWRS privatization."

TRADEMARK DISCLAIMER. Reference herein to any specific commercial product, process, or service by trade name, trademark, manufacturer, or otherwise, does not necessarily constitute or imply its endorsement, recomendation, or favoring by the United states Government or any agency thereof or its contractors or subcontractors.

Printed in the United States of America. To obtain copies of this document, contact: Document Control Services, P.O. Box 950, Mailstop H6-08, Richland WA 99352, Phone (509) 372-2420; Fax (509) 376-4989.
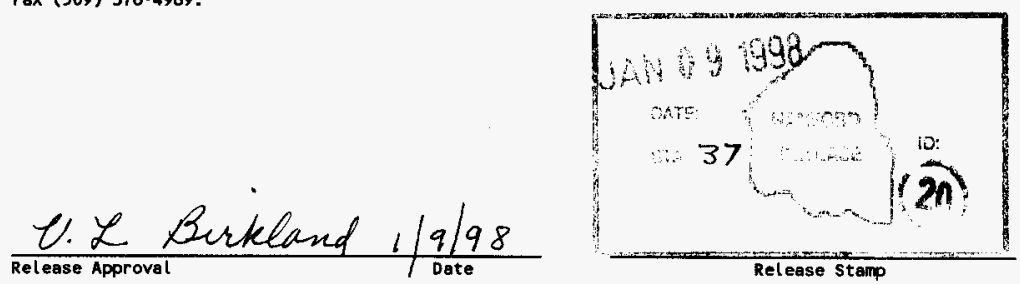


\section{RECORD OF REVISION}

(1) Document Number

HNF-2021

Page $T$

(2) Title Management Assessment of Tank Waste Remediation System Contractor Readiness to Proceed with Phase IB Privatization

CHANGE CONTROL RECORD

(3) Revision (4) Description of Change - Replace, Add, and Delete Page

0 (7) EDT-622847, $1 / 7 / 98$

1 RS Complete revision, per ECN-644555.

Authorized for Release

(5) Cog. Engr. (6) Cog. Hgr. Date

\begin{tabular}{l|l}
\hline MA Payne & LE Hall
\end{tabular}

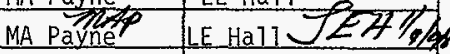


HNF-2021

Revision 1

\section{Management Assessment of Tank Waste Remediation System Contractor Readiness to Proceed With Phase 1B Privatization}

Prepared for the U.S. Department of Energy

$\$$ Fluor Daniel Hanford, Inc.

Richland, Washington

Hanford Management and Integration Contractor for the

U.S. Department of Energy under Contract DE-AC-0696-RL13200 


\title{
Management Assessment of Tank Waste Remediation System Contractor Readiness to Proceed With Phase 1B Privatization
}

\author{
M. A. Payne
}

Lockheed Martin Hanford Corporation

J. $\odot$. Honeyman

J. G. Kristofzski

W. T. Thompson

Lockheed Martin Hanford Corporation

P. J: Certa

Numatec Hanford Corporation

Date Published

January 1998

Prepared by Lockheed Martin Hanford Corporation Richland, Washington

Prepared for the U.S. Department of Energy

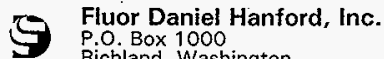

Richland, Washington

Hanford Management and Integration Contractor for the

U.S. Department of Energy under Contract DE-AC-0696-RL13200 
HNF-2021 Rev 1

This page intentionally left blank. 
Document Title: Management Assessment of Tank Waste Remediation System Contractor Readiness to Proceed With Phase 1B Privatization

Approved by:
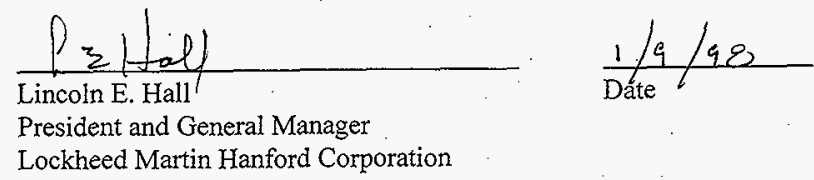

Lockheed Martin Hanford Corporation 
HNF-2021 Rev 1

This page intentionally left blank. 
HNF-2021 Rev 1

\section{EXECUTIVE SUMMARY}

This Management Assessment of Tank Waste Remediation System (TWRS) Contractor Readiness to Proceed With Phase $1 B$ Privatization documents the processes used to determine readiness to proceed with tank waste treatment technologies from private industry, now known as "TWRS privatization."

An overall systems approach was applied to develop action plans to support the retrieval and disposal mission of the TWRS Project. The systems and infrastructure required to support the mission are known. Required systems are either in place or plans have been developed to ensure they exist when needed. Since October 1996 a robust system engineering approach to establishing integrated Technical Baselines, work breakdown structures, tank farms organizational structure and configurations, work scope, and costs has become part of the culture within the TWRS Project. An analysis of the programmatic, management, and technical activities necessary to declare readiness to proceed with execution of the mission demonstrates that the system, personnel, and hardware will be online and ready to support the private contractors.

The systems approach included defining the retrieval and disposal mission requirements and evaluating the readiness of the Project Hanford Management Contract (PHMC) team to support initiation of waste processing by the private contractors in June 2002 and to receive. immobilized waste shortly thereafter. The Phase 1 feed delivery requirements from the private contractor Requests for Proposal were reviewed. Transfer piping routes were mapped, existing systems were evaluated, and upgrade requirements were defined. Requirements for infrastructure support to private contractors and for storage and disposal of immobilized tank 
wastes were also defined. Technical Basis Reviews were completed to define work scope in greater detail; cost estimates and associated year-by-year financial analyses were completed. The TWRS personnel training, qualifications, management systems, and procedures were reviewed and shown to be in place and ready or planned to support the Phase IB mission. Key assumptions and risks that could negatively impact mission success were evaluated and appropriate mitigative actions plans were planned and scheduled.

An integrated program management plan for the retrieval and disposal mission was developed to describe the overall management approach, organization roles and responsibilities, and overall performance measures.

This systematic review of the PHMC team's ability to support the retrieval and disposal mission concludes that the systems and infrastructure required to support the mission are understood and in place or plans are in place to ensure they exist when needed. A robust systems engineering culture, management system, and risk management program are in place. No technology breakthroughs are needed to achieve a manageable schedule for Phase $1 B$. The financial analysis demonstrated that overall costs are within 10 percent of current target baselines and are manageable. In short, the review demonstrates that the systems, personnel, and hardware upgrades are ready to proceed.

A global analysis of feed staging and processing requirements for Phase 2 was also conducted. The analysis focused on the feed delivery component of the mission. Feed delivery is technically and logistically more challenging than storing and disposing of immobilized wastes. The analysis indicates that the effectiveness and feasibility could be enhanced by extending the use of the Phase IB facilities. Continuing to operate these facilities would allow waste to be 
HNF-2021 Rev 1

processed in parallel with construction of Phase 2 facilities. This will result in a much smaller scale up for the full-scale production by allowing a decrease in the total vitrification plant capacity and reducing peak retrieval requirements to more manageable rates while still meeting the Hanford Federal Facility Agreement and Consent Order (Ecology et al. 1996) completion of processing dates.

There is a sense of urgency to the Northwest and the nation in moving forward with the removal of wastes from storage tanks at the Hanford Site and initiation of the immobilization of that waste. One of the primary sources of environmental risks at the Hanford Site results from waste leaking into the environment from the aging single-shell tanks. To date, 67 of these aging tanks have leaked, the remaining tanks are well beyond their design life; and will undoubtedly fail in the future, adding even more uncontrolled contamination to the environment.

To eliminate this additional future contamination, the U.S. Department of Energy (DOE) plans to remove the waste from the single-shell tanks, transfer it to the sound double-shell tank system, condition the waste in the double-shell tank system, and transfer the waste to immobilization facilities. From there the immobilized waste will be disposed in engineered facilities or stored until the national repository for high-level waste is available. Because the existing double-shell tank space is full or committed, it is necessary to initiate this immobilization process with waste in the double-shell tanks to make room for the single-shell tank waste.

In addition, many of the double-shell tanks experience periodic releases of flammable gases. Deflagration of these gases would lead to off-site releases that exceed risk acceptance guidelines. Currently, prevention of these releases depends heavily on administrative controls. 


\section{HNF-2021 Rev 1}

The long-term solution to these problem wastes is the retrieval and immobilization, which will eliminate the conditions that cause the generation and storage of explosive gases.

The PHMC team strongly recommends that DOE move forward with the Phase $I B$ program, which will initiate the process of waste removal and immobilization of double-shell tank waste, allowing the initiation of the single-shell tank retrieval process. In this manner, DOE will resolve the continuing issues of flammable gases, and build the foundation that will allow the removal of wastes from the single-shell tank system. The sooner we finish, the less high-level waste will leak into the environment. In the words of the TWRS Stakeholder Pariel, it is time to ". . get on with it." 


\section{CONTENTS}

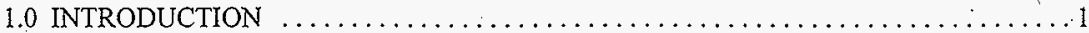

1.1 TOP-LEVEL MISSION DEFINITION AND OBJECTIVES . . . . . . . . . 2

1.2 SYSTEMS APPROACH TO MISSION ANALYSIS AND TECHNICAL

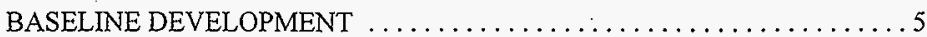

1.3 PROGRAM LEVEL O LOGIC FOR THE TANK WASTE REMEDIATION

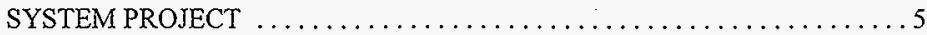

1.4 PROGRAM LOGIC REVIEWS FOR THE TANK WASTE REMEDIATION

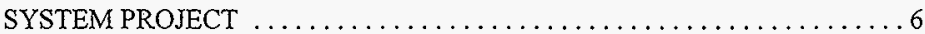

2.0 READINESS TO PROCEED REQUEST $\ldots \ldots \ldots \ldots \ldots \ldots \ldots \ldots \ldots \ldots \ldots \ldots \ldots \ldots \ldots$

3.0 READINESS TO PROCEED PROCESS AND APPRAISAL $\ldots \ldots \ldots \ldots \ldots \ldots \ldots$

3.1 READINESS TO PROCEED PROCESS $\ldots \ldots \ldots \ldots \ldots \ldots \ldots \ldots \ldots \ldots$

3.2. WORK BREAKDOWN STRUCTURE TO SUPPORT THE CRITICAL PATH

3.3 INTEGRATED PROGRAM PLAN AND OTHER SUPPORTING PLANS $\ldots .16$

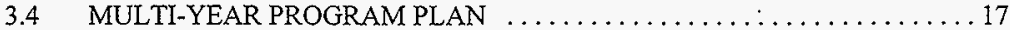

3.5 STRUCTURED INDEPENDENT APPRAISAL $\ldots \ldots \ldots \ldots \ldots \ldots \ldots$

4.0 PHASE 1B WASTE FEED DESCRIPTION, OPERATING SCENARIOS, AND

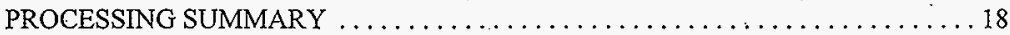

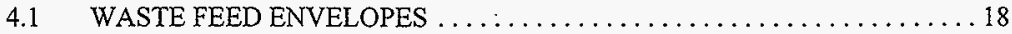

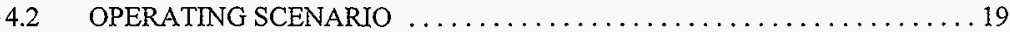

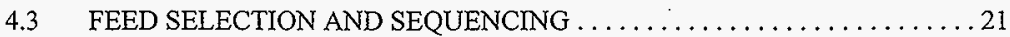

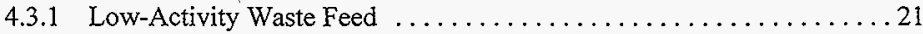

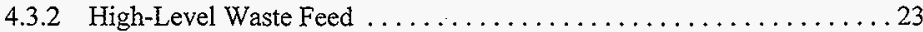

4.4 WASTE TRANSFERS TO SUPPORT THE OPERATING SCENARIO $\ldots \ldots 24$

4.5 STAGING STRATEGY AND BATCH CYCLE TIME $\ldots \ldots \ldots \ldots \ldots \ldots 27$

4.6 IMMOBILIZED LOW-ACTIVITY WASTE $\ldots \ldots \ldots \ldots \ldots \ldots \ldots \ldots \ldots 27$

4.7 IMMOBILIZED HIGH-LEVEL WASTE $\ldots \ldots \ldots \ldots \ldots \ldots \ldots \ldots \ldots \ldots \ldots$

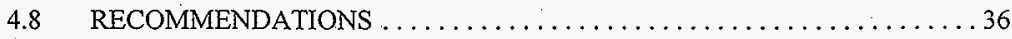

5.0 EQUIPMENT UPGRADES AND NEW FACLLITIES TO SUPPORT PHASE $1 \mathrm{~B} \ldots \ldots 39$

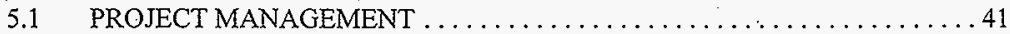

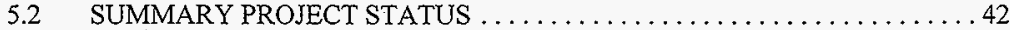

6.0 OPERATIONS SUPPORT TO PHASE 1B RETRIEVAL $\ldots \ldots \ldots \ldots \ldots \ldots \ldots . \ldots 4$

7.0 MAJOR RISKS AND UNCERTAINTIES $\ldots \ldots \ldots \ldots \ldots \ldots \ldots \ldots \ldots \ldots \ldots \ldots \ldots \ldots \ldots . \ldots$.

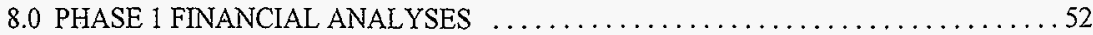




\section{CONTENTS (Continued)}

9.0 PHASE 1 SUMMARY AND CONCLUSIONS $\ldots \ldots \ldots \ldots \ldots \ldots \ldots \ldots \ldots \ldots \ldots \ldots \ldots \ldots \ldots$

10.0 PHASE 2 PROCESSING RATE ANALYSIS AND RECOMMENDATIONS $\ldots \ldots \ldots 53$

10.1 PHASE 2 FEED DELIVERY RATE REQUIREMENTS $\ldots \ldots \ldots \ldots \ldots \ldots 54$

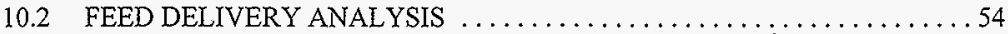

10.3 MELTER CAPACITY SCALE-UP COMPARISON WTTH COMMERCIAL

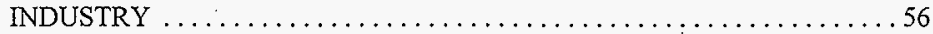

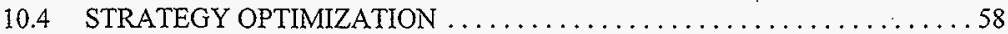

10.5 RECOMMENDATIONS TO ACCELERATE THE REMOVAL OF WASTE FROM SINGLE-SHELL TANKS $\ldots \ldots \ldots \ldots \ldots \ldots \ldots \ldots \ldots \ldots$

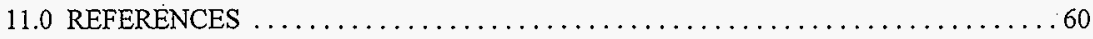

\section{APPENDIX}

EQUIPMENT CONFIGURATIONS TO SUPPORT PHASE 1B FEED DELIVERY FOR LOW-ACTIVITY WASTE AND HIGH-LEVEL WASTE 


\section{LIST OF FIGURES}

1. Summary Schedule of Privatization Phase 18 Decisions $\ldots \ldots \ldots \ldots \ldots \ldots \ldots \ldots \ldots \ldots$

2. Relative Ages of Single-Shell Tanks and Double-Shell Tanks $\ldots \ldots \ldots \ldots \ldots \ldots \ldots$

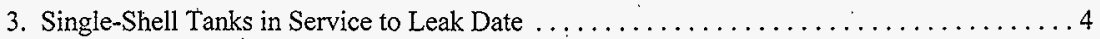

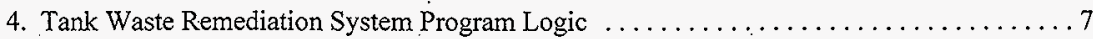

5. Top-Level Tank Waste Remediation System Schedule $\ldots \ldots \ldots \ldots \ldots \ldots \ldots$

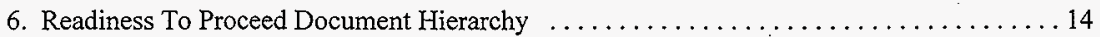

7. Systems Approach to Tank Waste Retrieval ......................... 15

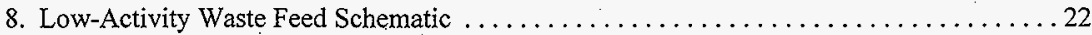

9. Diagram of Staging Transfers in Chronological Order (Low-Activity Waste Batches 1-3) Baseline ............................................ 31

10. Staging Transfers for the First Low-Activity Waste Feed Batch $\ldots \ldots \ldots \ldots \ldots \ldots 32$

11. Retrieval, Staging, and Feed Qualification Times $\ldots \ldots \ldots \ldots \ldots \ldots \ldots \ldots \ldots$

12. Immobilized Low-Activity Waste Disposal Capacity Versus Demand $\ldots \ldots \ldots \ldots \ldots . \ldots 35$

13. Immobilized High-Level Waste Interim Storage Capacity Versus Demand . . . . . . 37

14. Summary Schedule of Construction Project Activities to Support Phase 1 B $\ldots \ldots \ldots \ldots 43$

15. Top Level Summary of Technical Basis for Operations ................... 45

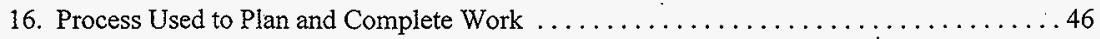

17. Volume of Work and Low Rate of Off Normal Events $\ldots \ldots \ldots \ldots \ldots \ldots \ldots \ldots$

18. Trends in Lost Work Day Case Rates and Recordable Injuries . . . . . . . . . . . . 47

19. Phase $1 \mathrm{~B}$ and Phase 2 Low-Activity Waste Processing Rates $\ldots \ldots \ldots \ldots \ldots \ldots$

20. Tank Farm System Retrieval and Transfer Infrastructure $\ldots \ldots \ldots \ldots \ldots \ldots \ldots . \ldots \ldots 7$

21. Example Mission Improvements - Low-Activity Waste Processing . . . . . . . . . 59 


\section{LIST OF TABLES}

1. Major Tank Waste Remediation System Milestones $\ldots \ldots \ldots \ldots \ldots \ldots \ldots \ldots \ldots$

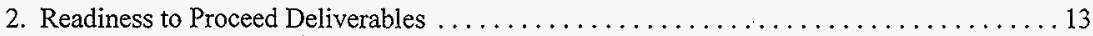

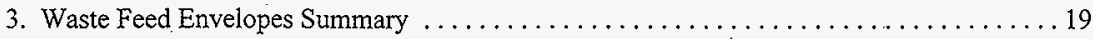

4. Major Requirements that Influence the Operating Scenario $\ldots \ldots \ldots \ldots \ldots \ldots \ldots$

5. Major Enabling Assumptions That Influence the Operating Scenario $\ldots \ldots \ldots \ldots \ldots \ldots 21$

6. Low-Activity Waste

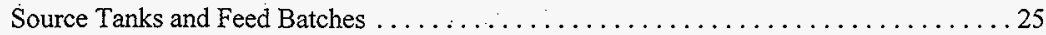

7. Comparison of Low-Activity Waste and High-Level Waste Feed Quantities with Contract

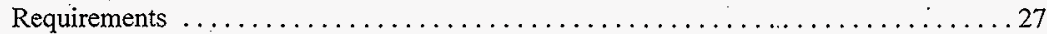

8. High-Level Waste Source

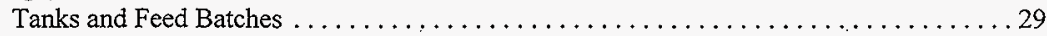

9. Typical Low-Activity Waste Feed Delivery

Batch Cycle Time for Envelope A. . ........................... 34

10. Summary of Projects that will be Completed in Fiscal Year $1998 \ldots \ldots \ldots \ldots \ldots \ldots \ldots 40$

11. Summary of the Projects, Scope, Schedules and Costs $\ldots \ldots \ldots \ldots \ldots \ldots \ldots \ldots \ldots \ldots$

12. Summary of Facility Evaluation Board Assessments

of Tank Waste Remediation System Facilities . . . . . . . . . . . . . . . . . . 49

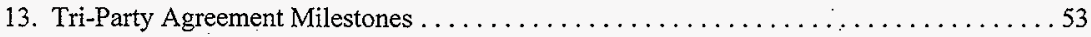

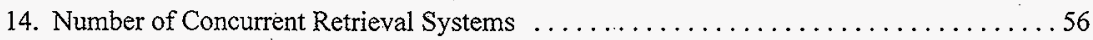

15. Comparison of Tank Waste Remediation System Planning Baseline and Example Mission Improvements Case ..................................... 59 


\section{LIST OF TERMS}

BIO

DNFSB

DOE

DST

Ecology

EPA

FY

HLW

IHLW

ILAW

IRT

LAW

MT

PHMC

PNNL

RL

RTP

SST

Tri-Party Agreement

TRU

TWR

TWRS

WBS
Basis for Interim Operation

Defense Nuclear Facility Safety Board

U.S. Department of Energy

double-shell tank

Washington State Department of Ecology.

U.S. Environmental Protection Agency

fiscal year

high-level waste

immobilized high-level waste

immobilized low-activity waste

independent review team

low-activity waste

metric ton

Project Hanford Management Contract

Pacific Northwest National Laboratory

U.S. Department of Energy, Richland Operations Office readiness to proceed

single-shell tank

Hanford Federal Facility Agreement and Consent Order transuranic (waste)

tank waste retrieval

Tank Waste Remediation System

work breakdown structure 


\section{MANAGEMENT ASSESSMENT OF TANK WASTE REMEDIATION SYSTEM CONTRACTOR READINESS TO PROCEED WITH PHASE 1B PRIVATIZATION}

\subsection{INTRODUCTION}

On October 1, 1996, the U.S. Department of Energy (DOE), Richland Operations Office (RL) awarded the DE-AC06-96RL13200, Project Hanford Management Contract (PHMC) (RL 1996b), to a team of contractors to manage and integrate cleanup of DOE former nuclear production facilities at the Hanford Site. This contract award was predicated on the PHMC team bringing the technical and systems engineering skills to develop a technically Integrated Baseline for the Hanford Site and, specifically, the Tank Waste Remediation System (TWRS) Project. These skills are fundamental to RL's strategy to solicit a tank waste treatment capability from private industry. The strategy for waste treatment, now known as "Tank Waste Remediation System (TWRS) privatization," was placed under contract with two private contractors, British Nuclear Fuels and Lockheed Martin Environmental Applications Systems, in September 1996. The TWRS privatization project comprises two parts: Phase 1, the demonstration phase; and Phase 2, full-scale production mode. Both private contractors are participating in Phase 1 , which also comprises two parts: Phase 1A, preliminary technical phase; and Phase 1B, construction and operation of the test technologies.

The demonstration facilities being built for Phase 1B are scheduled for operation from 2002 through 2005 , with options to run through 2011 . Up to 13 percent of the total waste in the Hanford Site tanks will be processed in the demonstration facilities. During Phase 1, wastes from up to 6 of the flammable gas watch list tanks will be removed and treated, and a largé percentage of the radioactivity in double-shell tanks (DSTs) will be immobilized.

In parallel with these events, RL requested the PHMC team to develop the Technical Baseline documentation that will establish readiness to support a tank waste retrieval (TWR) and disposal program through 2024. Plans to proceed with the Phase $1 \mathrm{~B}$ waste feed delivery were provided to RL in January 1998. The RL is also reviewing DOE/EIS-0189, Tank Waste Remediation System, Hanford Site, Richland, Washington, Final Environmental Impact Statement (DOE and Ecology 1996) as committed in 62 FR 8693, Record of Decision for the Tank Waste Remediation System, Hanford Site, Richland, WA. These separate actions, taken as a whole, will constitute the technical and financial basis for continuation of the program. Figure 1 summarizes these actions.

Subsequent sections of this document will describe the readiness to proceed (RTP) request, the RTP process and appraisal, the Phase $1 \mathrm{~B}$ processing summary and mission analysis, equipment upgrades, operations readiness, major risks and uncertainties, Phase 1 financial . 
Figure 1. Summary Schedule of Privatization Phase 1B Decisions.

\section{Privatization \\ Proposals}

\section{Tank Waste \\ Retrieval}

Readiness to

Proceed

Evaluation

EIS ROD Review

EIS = Environmental Impact Statement

ROD = Record of Decision

analyses, Phase 1 summary and conclusions, and Phase 2 processing rate analysis and recommendations.

\subsection{TOP-LEVEL MISSION DEFINITION AND OBJECTIVES}

The Hanford Site Technical Database (HSTD n.d.) establishes the top-level functional requirements that define the Hanford Site cleanup mission. This baseline allocates requirements to the projects that make up the TWRS Project, defines primary interfaces, and bounds the mission of the TWRS Project.

The principal objective of the TWRS Project mission is to reduce and eliminate the risk to the public and the environment that results from about 54 million gallons of mixed and highlevel waste (HLW) stored in 177 underground tanks: 149 single-shell tanks (SSTs) and 28 DSTs. These tanks contain approximately 292,000 metric tons (MT) of process chemicals and 228 mega-curies of radionuclides. The TWRS Project is also responsible for the majority of the miscellaneous tanks. Tank wastes are in the form of liquids, salt cakes, and sludges. To date, approximately 1 million gallons, containing about 300,000-1,000,000 curies of radioactivity and significant quantities of hazardous chemicals have leaked from the SSTs. Recent Pacific 
Northwest National Laboratory (PNNL) reports indicate that some of the SST leakage has reached the water below the surface of the Site. The older SSTs will continue to pose risk to the public, the environment, and Site workers from potential leakage over both the near and long term. These aging tanks are well beyond their design life and will undoubtedly fail in the future, adding even more uncontrolled contamination to the environment. Figure 2 shows the relative ages of the SSTs and DSTs today and at the completion of the retrieval and closure missions in 2028. Some SSTs developed leaks shortly after being placed in service. These leaks were attributed to the usage of the tanks for processing activities. The apparent decrease in the number of SSTs identified as leakers after about 35 years is more likely due to removal of liquids from saltwell pumping.

Figure 2. Relative Ages of Single-Shell Tanks and Double-Shell Tanks:

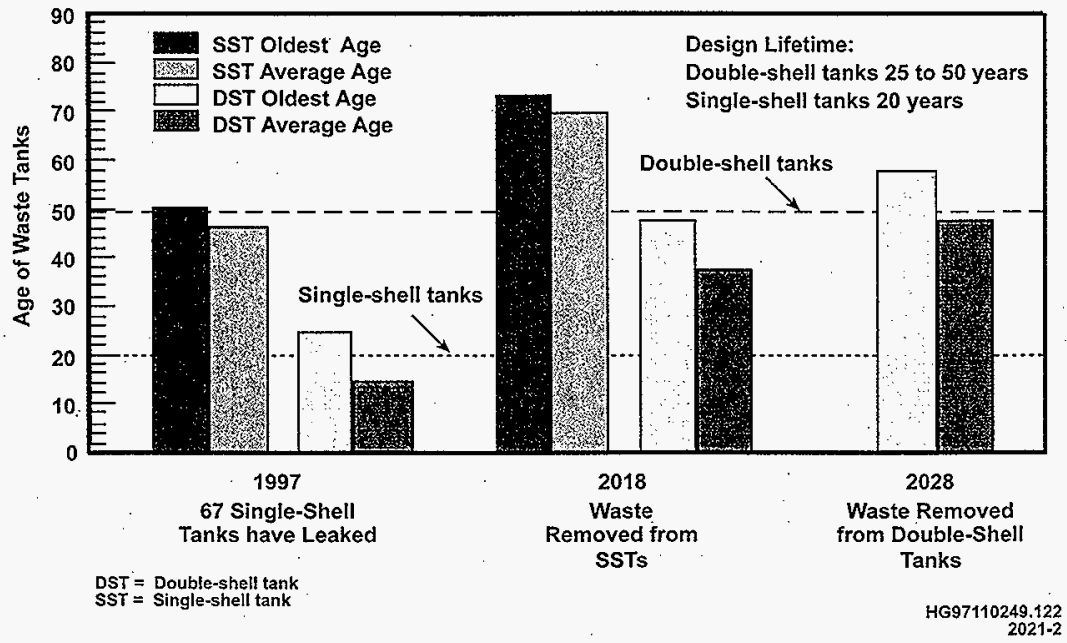

To eliminate additional contamination, DOE plans to transfer the waste from the SSTs to the sound DST system, condition the waste in the DST system, and transfer the waste to immobilization facilities. Upon return the immobilized waste will be disposed in engineered facilities or stored until the national HLW repository is available. Because the existing DST space is full or committed, it is necessary to initiate the removal and immobilization process with waste in the DSTs to make room for the SST waste. Figure 3 shows the time durations from when 67 of the 149 SSTs were placed in service until leaks developed.

Retrieval and immobilization of waste from the DSTs also is a long-term solution to eliminate conditions in many DSTs that cause the generation, retention, and periodic release of flammable gases. Deflagration of these gases would lead to off-site releases that exceed risk 
HNF-2021 Rev 1

Figure 3. Single-Shell Tanks in Service to Leak Date.

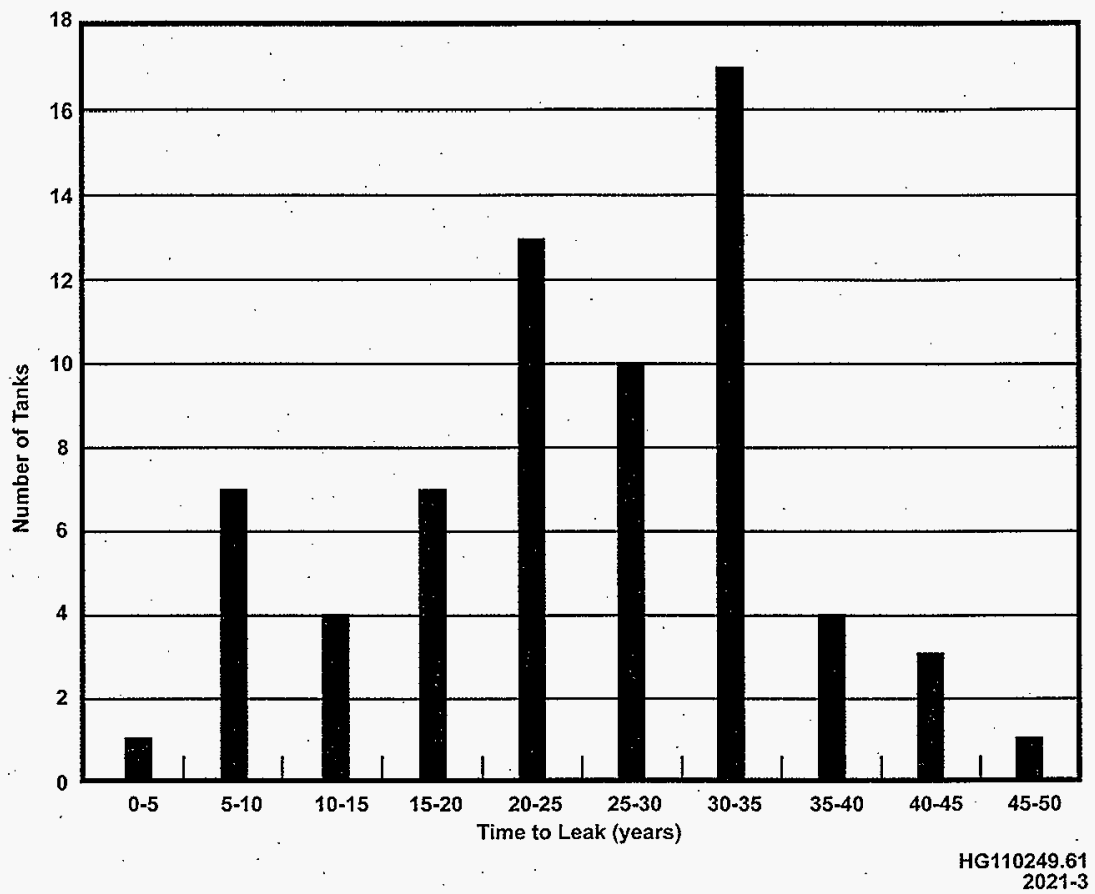

acceptance guidelines. Currently, prevention of these releases depends on administrative controls.

The 1996 DOE Environmental Impact Statement (DOE and Ecology 1996) compared a range of alternatives including retrieval, processing, and immobilization with in-situ and "do nothing" alternatives. In all cases, billions of dollars would be required to retrieve and process the waste or, alternatively, if nothing were done, to rebuild compliant storage tanks to safely store and manage the waste for the foreseeable future. The DOE decided to move forward with a compliant retrieve, process, and immobilize approach, rather than construct replacement storage tanks, or treat and dispose of the waste in situ. Also the DOE decided to use an initial phase to demonstrate low-activity waste (LAW) and HLW separation and immobilization, and to process up to 13 percent of the tank waste (Phase 1 Privatization). This will be followed by a larger scale production phase to complete the mission (Phase 2 Privatization). This decision appears to be broadly endorsed by the Washington State Department of Ecology (Ecology), 
U.S. Environmental Protection Agency (EPA), Hanford Advisory Board, the Defense Nuclear Facilities Safety Board (DNFSB), the Indian Nations, and other vital stakeholders.

\subsection{SYSTEMS APPROACH TO MISSION ANALYSIS AND TECHNICAL BASELINE DEVELOPMENT}

Between October 1996 and September 1997, both RL and the PHMC team worked to refine the Retrieval and Disposal Mission; to develop a technically Integrated Baseline to achieve the mission and shape it to funding limitations; to decompose the work scope into a Master Work Breakdown Structure (WBS) that recognizes the integrated work scope to achieve the mission; and to determine the tank upgrades and transfer pipeline improvements necessary to meet the batch feed rates assumed for the private contractors. The Master WBS also addresses the infrastructure support to the private contractors and disposition of the immobilized waste products. These efforts represent a significant improvement to the Technical Baseline.

\subsection{PROGRAM LEVEL 0 LOGIC FOR THE TANK WASTE REMEDIATION SYSTEM PROJECT}

-The PHMC team developed the Level 0 Logics (FDH 1998) as a tool for establishing a clear direction of logical relationships and sequences of activities necessary to achieve the integrated mission of the TWRS Project. The program Level 0 logic is divided into four primary sections (Figure 4): Safe Storage, Phase 1 Privatization, Phase 2 Privatization, and Tank and Facility Closure. The top-level time frame of the program execution during Phase 1 is also presented in Figure 5. The major programmatic milestones that structure the program are summarized in Table 1. These milestones are based on the Hanford Federal Facility Agreement and Consent Order (Tri-Party Agreement) (Ecology et al. 1996) amendments (negotiated by RL, Ecology, and EPA) and incorporate the phased privatization approach.

Table 1. Major Tank Waste Remediation System Milestones.

\begin{tabular}{|l|l|}
\hline \multicolumn{1}{|c|}{ Milestone } & \multicolumn{1}{c|}{ Date } \\
\hline Initiate LAW Immobilization (Phase 1) & June 2002 \\
\hline Complete Closure of all SSTs (M-45-00) & September 2024 \\
\hline Complete SST Waste Retrieval (M-45-05) & September 2018 \\
\hline Complete HLW Immobilization(M-51-00) & December 2028 \\
\hline Initiate HLW Immobilization (Phase 1)(M-51-03) & December 2009 \\
\hline Complete LLW Immobilization (M-60-00) & December 2024 \\
\hline
\end{tabular}

HLW $=$ high-level waste.

$\mathrm{LAW}=$ low-activity waste.

LLW $=$ low-level waste.

SST $=$ single-shell tank. 


\subsection{PROGRAM LOGIC REVIEWS FOR THE TANK WASTE REMEDIATION SYSTEM PROJECT}

The Program Logic for the TWRS Project was reviewed by the senior management of Ecology, RL, and the PHMC team on November 13 and 14, 1997. Unanimous support for the Technical Baseline was established. On November 20,1997, RL and the PHMC team presented this Technical Baseline to the DNFSB and received an enthusiastic endorsement. The DNFSB Technical Report Number 16, "Integrated Safety Management" (DNFSB 1997), and Ecology letter to John Wagoner, "Department of Energy's Ability to Declare Readiness to Proceed for Privatization" (Ecology 1997), document the DNFSB and Ecology concurrence with the systems approach. This baseline establishes a technically defensible, integrated systems approach that will achieve retrieval, transfer of waste to the privatized facilities, and storage commencing in June 2002 and beyond.

\subsection{READINESS TO PROCEED REQUEST}

The RL requested the PHMC team to prepare an RTP memorandum that describes the technical, programmatic, and managerial activities necessary to support execution of the Phase 1 private contract (Letter 97-WDD-129, Contract Number DE-AC06-96RL13200, Tank Waste Remediation System (TWRS) Privatization - Hanford Contractors Readiness to Proceed (Taylor 1997). The referenced letter requested that the PHMC team submit a plan outlining the key deliverables that the private contractor will use to assess their capability to support Phase $1 \mathrm{~B}$ and discussed RL plans to assess the PHMC team's RTP. The PHMC RTP team responded with FNF-1241, Readiness To Proceed Plan for M\&I Contractor Workscope in Support of TWRS Phase 1B Privatization (Wojtasek 1997), which was submitted on October 31, 1997.

Taylor (1997), with attachments and checklist, is a general set of functional requirements from which both the contractor and government can quantitatively judge RTP with privatization. From these requirements, the PHMC team derived a second tier with more details for the deliverables that will enable DOE to meet the Energy Secretary Acquisition Advisory Board requirements and support RTP determination.

\subsection{READINESS TO PROCEED PROCESS AND APPRAISAL}

This section describes the process used to develop the RTP deliverables (Table 2). Figure 6 depicts the document hierarchy for RTP deliverables and associated supporting documents. The starting point for the RTP analysis documentation was built on the Technical Baseline described in Section 1.0. 


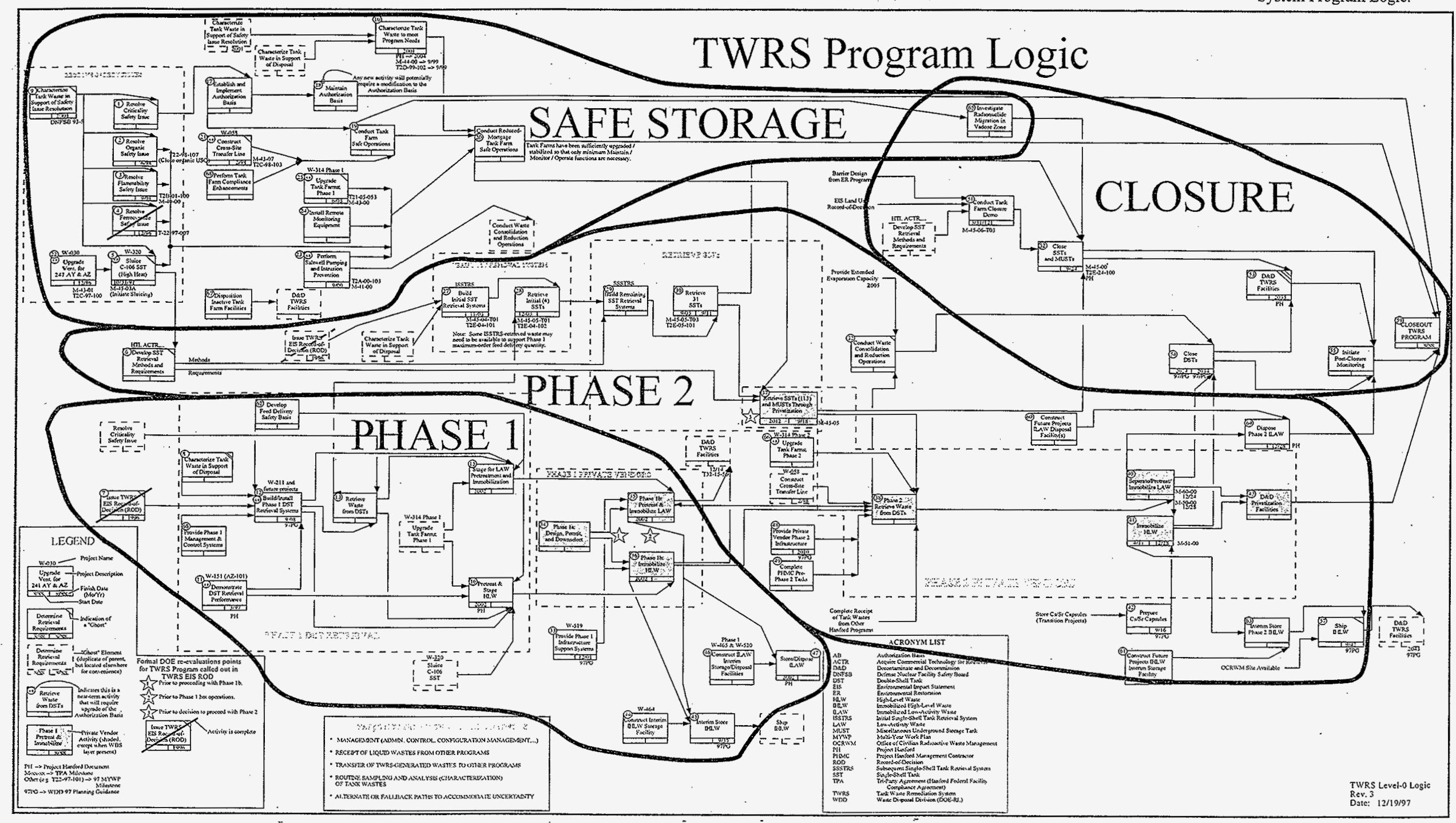


Figure 5. Top-Level Tank Waste Remediation System Schedule. (2 Sheets)

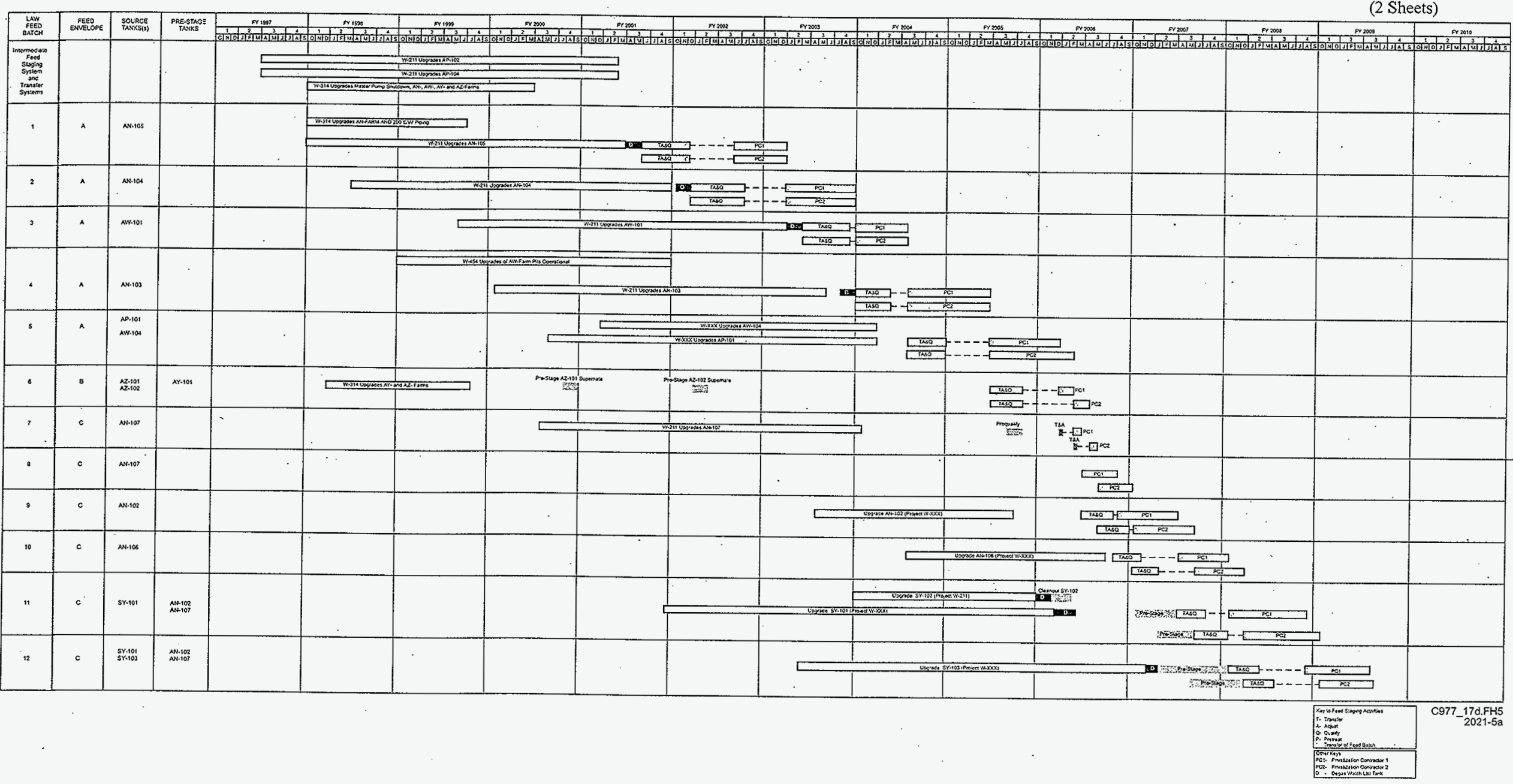


Figure 5. Top-Level Tank Waste Remediation System Schedule. (2 Sheets)
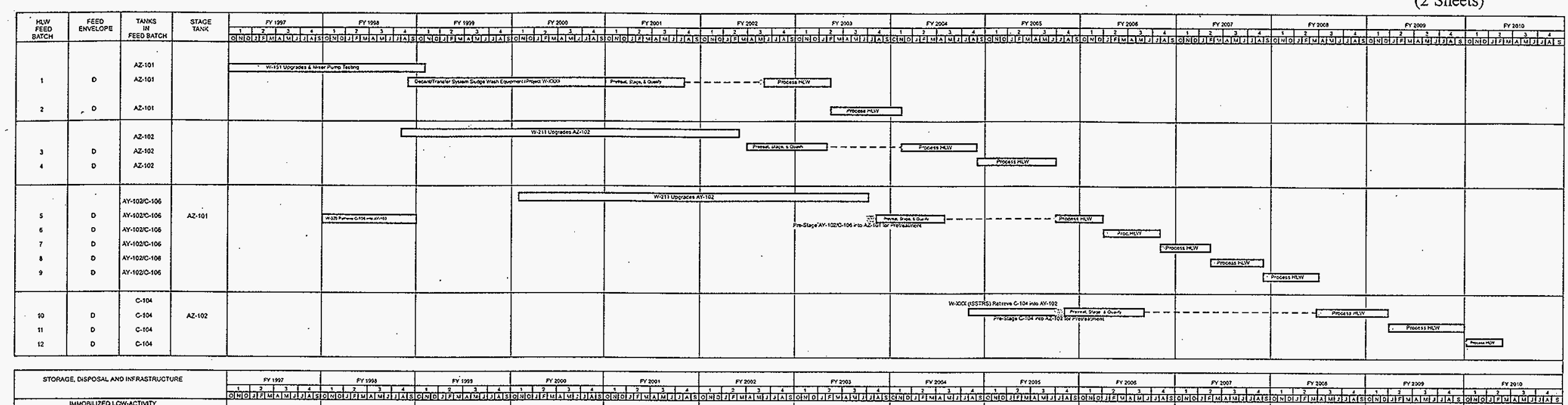

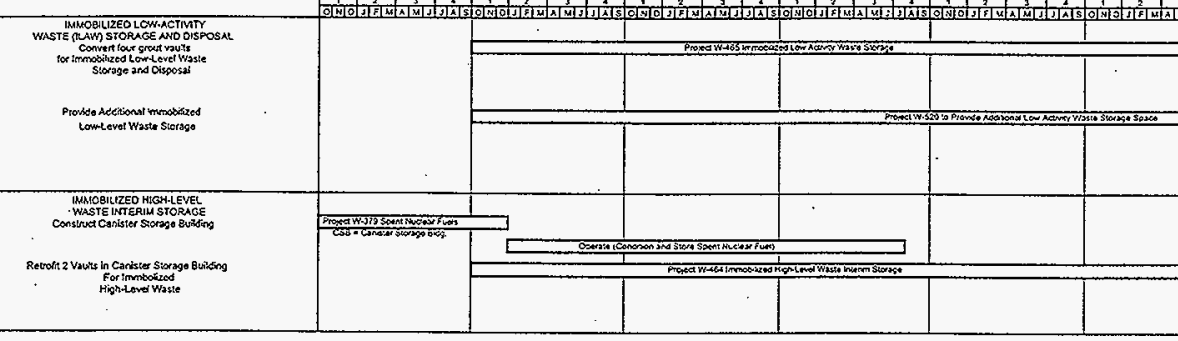

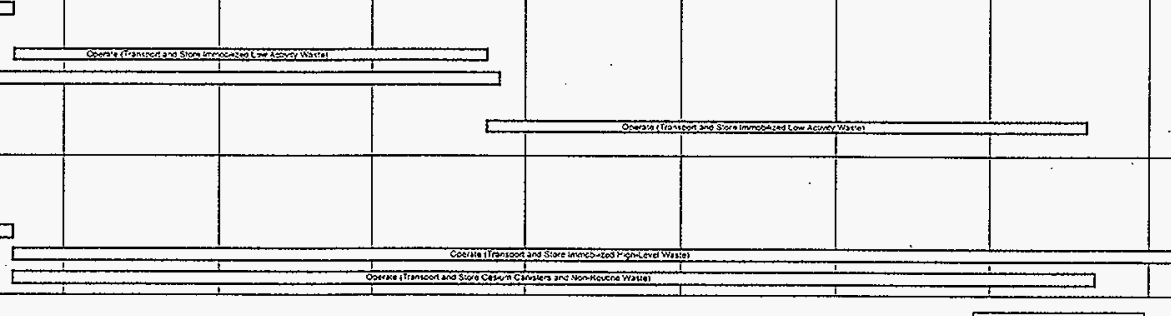


Table 2. Readiness to Proceed Deliverables.

HNF-SD-WM-MAR-008, Tank Waste Remediation System Mission Analysis Report

HNF-1883, Tank Waste Remediation System Program Plan

HNF-1946, Tank Waste Remediation System Retrieval and Disposal Mission Initial Updated Baseline Summary

HNF-2019, Tank Waste Remediation System Retrieval and Disposal Mission Readiness-to-Proceed Memorandum ${ }^{d}$

HNF-2017, Tank Waste Remediation System Retrieval and Disposal Mission Phase I Financial Analysis

HNF-2020, Tank Waste Remediation System Retrieval and Disposal Mission Readiness-to-Proceed Guidance and Requirements to Deliverables Crosswalk

HNF-1945, Tank Waste Remediation System Retrieval and Disposal Mission Key Enabling Assumptions ${ }^{\mathrm{B}}$

'Acrec, C. D., Jr., 1998, Tank Waste Remediation System Mission Analysis Report, HNF-SD-WM-MAR-008, Rev. 3, prepared by Lockheed Martin Hanford Corporation for Fluor Daniel Hanford, Inc., Richland, Washington.

'Freeman, D. V., 1998, Tank Waste Remediation System Program Plan, HNF-1883, Rev. 1; prepared by Lockheed Martin Hanford Corporation for Fluor Daniel Hanford, Inc., Richland, Washington.

'Swita, W. R., M. R. Lewis, and M. J. O'Neill, 1998, Tank Waste Remediation System Retrieval and Disposal Mission Initial Updated Baseline Summary, HNF-1946, Rev. 1, prepared by Lockheed Martin Hanford Corporation for Fluor Daniel Hanford, Inc., Richland, Washington.

Jordan, K. N., and H. L. Boston, 1998, Tank Waste Remediation System Retrieval and Disposal Mission Readiness-10-Proceed Memorandim, HNF-2019, Rev. 0, prepared by Lockheed Martin Hanford Corporation for Fluor Daniel Hanford, Inc., Richland, Washington.

'Wells, M. W., 1998, Tank Waste Remediation System Retrieval and Disposal Mission Phase 1 Financial Analysis, HNF-2017, Rev. 1, prepared by Lockheed Martin Hanford Corporation for Fluor Daniel Hanford, Inc., Richland, Washington.

'Hall, C. A., 1998, Tank Waste Remediation System Retrieval and Disposal Mission Readiness-fo-Proceed Guidance and Reguirements to Deliverables Crosswalk, HNF-2020, Rev. 0, prepared by Lockheed Martin Hanford Corporation for Flior Daniel Hanford, Inc., Richland, Washington.

${ }^{8}$ Baldwin, J. H., T. J. McLaughlin, R. D. Potter, and R. L. Treat, 1998, Tank Waste Remediation System Retriéval and Disposal Mission Key Enabling Assumptions, HNF-1945, Rev. 0, prepared by Lockheed Martin Hanford Corporation for Fluor Daniel Hanford, Inc., Richland, Washington.

\subsection{READINESS TO PROCEED PROCESS}

A comprehensive systems approach was used to define the mission requirements for retrieval and disposal of immobilized waste and to evaluate the readiness of the PHMC team to support initiation of waste processing by private contractors by June 2002. Figure 7 provides a flow chart of the key activities completed to define and assess readiness. Both the Hanford Site Technical Database and DE-AC06-96RL13309, Lockheed Martin Advanced Environmental Systems Privatization Contract (RL 1996a), assigned requirements to TWRS. An updated HNF-SD-WM-MAR-008, Tank Waste Remediation System Mission Analysis Report (Acree 1998) was prepared based on these requirements. The scope, boundary conditions, and enabling assumptions from the Mission Analysis Report were used to update the Level 0 program logic. The logic outlined the entire TWRS Project including storage and disposal, Phase 1 waste vitrification demonstration, Phase 2 full-scale production, storage of immobilized wastes, and closure of the tank farms. The Level 0 Logic (FDH 1998) was decomposed, and the 


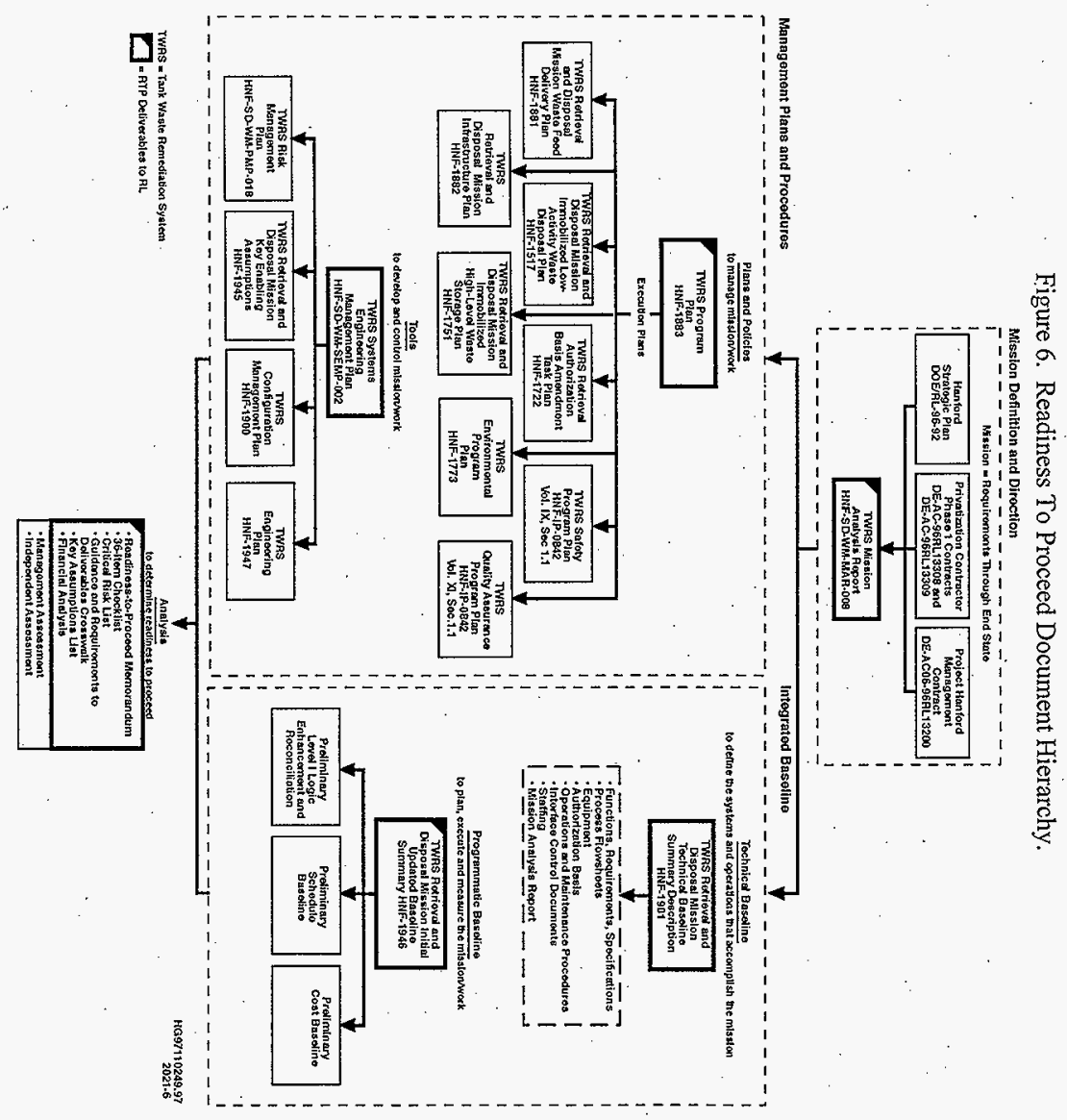


Figure 7. Systems Approach to Tank Waste Retrieval.

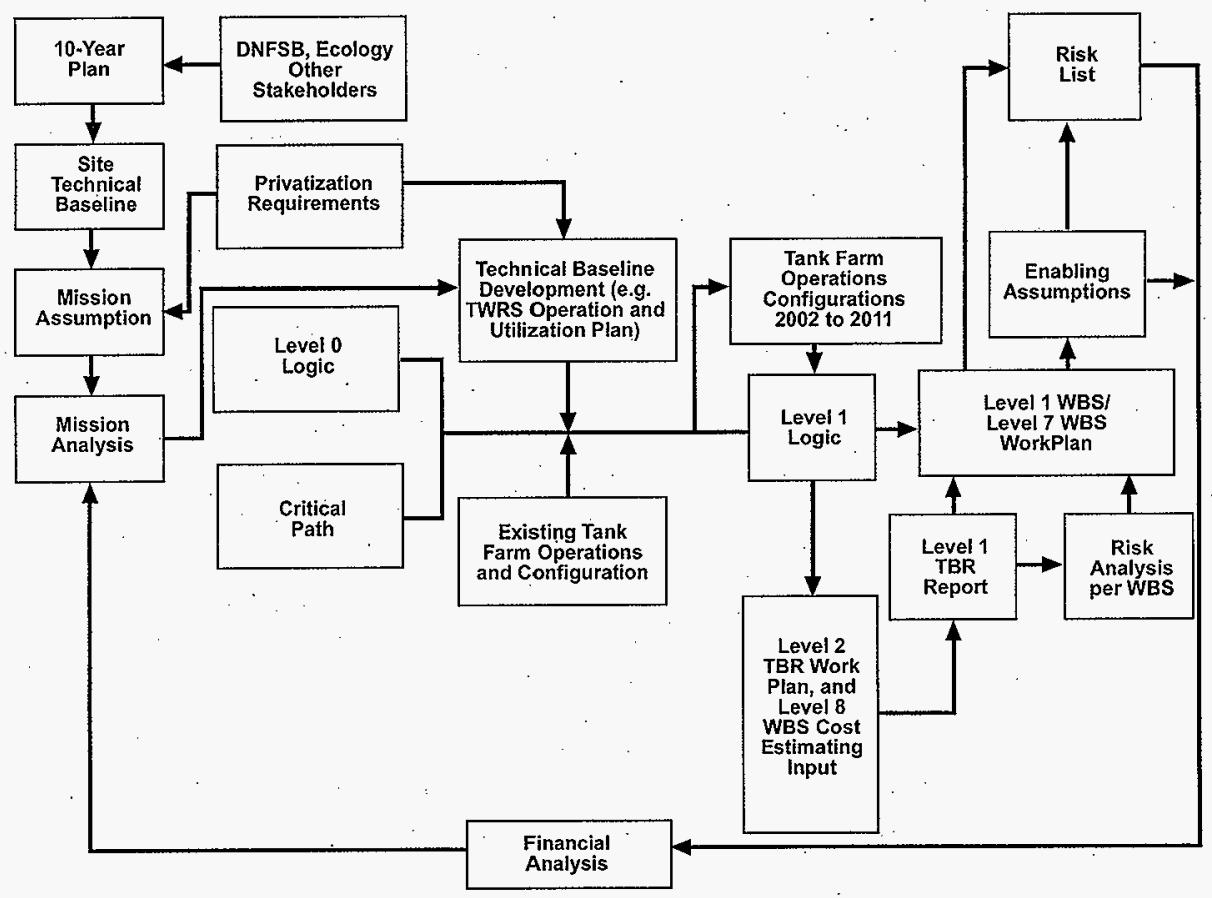

DNFSB = Defense Nuclear Facilities Safety Board ECOLOGY $=$ Washington State Department of Ecology

TBR = Technical Basis Review

TWRS = Tank Waste Remediation System

WBS $=$ Work Breakdown Structure 
critical path to deliver feed was developed. Existing systems were evaluated and upgrade requirements were defined. From the Level 1 Logic (Work Breakdown Structure [WBS] Level 7), work scopes and schedules were developed. Technical Basis Reviews were completed to further define work scope at the WBS Level 8, and cost estimates were developed. The HNF-SD-WM-MAR-008 (Acree 1998) reflects this updated Technical Baseline, progress toward resolving top-level enabling assumptions and risks, and incorporation of technical analyses that support definition of the TWRS Project. These work scopes, cost estimates, and the associated year-by-year financial analyses were completed and will form the basis of a change request to the multi-year work plans. This documentation recognizes the current fiscal year (FY) 1998 configuration while establishing the framework for configuration maturation to Phase 1 and Phase 2.

\subsection{WORK BREAKDOWN STRUCTURE TO SUPPORT THE CRITICAL PATH}

The activities and work scope described above were incorporated into the Retrieval and Disposal Mission WBS. This WBS describes the budgeted scope needed to support the critical path schedule. Each of the WBS cost elements supporting the critical path was evaluated for risk and risk mitigation actions, and the budgetary enabling assumptions were cataloged and evaluated. Key enabling assumptions are discussed in HNF-1945, Tank Waste Remediation System Retrieval and Disposal Mission Key Enabling Assumptions (Baldwin et al. 1998). Critical risks are described in the Tank Waste Remediation System Retrieval and Disposal Mission Risk List attached to the RTP memorandum (Jordon \& Boston 1998). The financial analyses are contained in HNF-2017, Tank Waste Remediation System Retrieval Financial Analysis (Wells 1998) in greater detail.

\subsection{INTEGRATED PROGRAM PLAN AND OTHER SUPPORTING PLANS}

The HNF-1883, Tank Waste Remediation System Program Plan (Freeman 1998), was developed to describe the overall management approach, organizational roles and responsibilities, and overall performance measures. Supporting discipline plans were developed also.

The INF-1773, Tank Waste Remediation System Environmental Program Plan (Borneman 1998); WHC-SD-WM-HSP-002, Tank Farm Health and Safety Plan (Mickle 1995); and HNF-IP-0842, TWRS Administration, Volume XI, Section 1.1 (LMHC 1997), were updated or created to describe how compliance to environmental, health, safety, and quality are integrated into the conduct of work. The plans describe the further implementation of a safety management system to the worker safety level and implementation of quality assurance requirements and continuous process improvements to support the retrieval and disposal mission. 
The HNF-1947, Tank Waste Remediation System Engineering Plan (Rifaey 1998), was developed to describe the engineering process and design authority controls that will be in place to support the Technical Baseline definition and manage its evolution and implementation to the field operations. This plan provides the vision for the engineering required to support the retrieval and disposal mission through Phase 1 and Phase 2. Further, the plan describes the . approach for moving from the "as is" condition of engineering practices, systems, and facilities to the desired "to be" configuration.

The HNF-SD-WM-SEMP-002, Tank Waste Remediation System Systems Engineering Management Plan (Peck 1998) was developed to ensure that the requirements assigned to the TWRS Project by the Site Integrated Baseline were captured, integrated, and assigned in a systematic way to the conduct of TWRS work. The Systems Engineering Management Plan describes the evolution of the technical requirements baseline from the highest levels of the TWRS Project, to the project-specific design requirements for individual construction projects. The Systems Engineering Management Plan is integrated with the other plans and procedures, assuring that execution of activities throughout the TWRS Project use good systems engineering practice.

The HNF-1900, Tank Waste Remediation System Configuration Management Plan (Vann et al. 1998) was developed to ensure that the conduct of the work within TWRS facilities is documented and managed in a structured, controlled manner. Implementation of the plan will ensure that the facilities and equipment, supporting design and authorization documents, and operating procedures are current, and represent a consistent, desired configuration.

A TWRS Risk Management Plan (HNF-SD-WM-PMP-018) was developed. This plan outlines the format and plan for determining and analyzing risks that may interfere with successful mission accomplishment.

\subsection{MULTI-YEAR PROGRAM PLAN}

Supporting logic decomposition and Technical Baseline requirements were used to develop cost and schedule information that will be integrated into HNF-SP-1230, Tank Waste Remediation System Fiscal Year 1998 Multi-Year. Work Plan WBS 1.1 (Lenseigne 1997). The RTP process developed requirements and planning information at a much greater level of detail than was used to support the existing Multi-Year Work Plan. This greater level of detail will be incorporated into the Multi-Year Work Plan baseline updates. In addition, upgrades to management, business, and technical systems; and work processes are planned to streamline and improve the overall effectiveness. These upgrades will also reduce costs and increase schedule contingency. 


\subsection{STRUCTURED INDEPENDENT APPRAISAL}

A structured independent appraisal of the PHMC team's RTP was conducted in early December 1997. The RTP Independent Review Team (IRT) consisted of consultants and executives with extensive experience in operations and maintenance, environmental and safety, quality assurance, technical baseline, business management, and representatives from projects and stakeholder groups. The IRT used a structured process to review the RTP documentation against requirements. The process included the following:

- Identification of requirements and criteria

- Use of review sheets prepared specific to each area assessed

- Review of RTP documentation

- Interviews with the PHMC RTP team

- Preparation of a report to document the assessment.

The IRT concluded that the PHMC team has demonstrated a clear and complete understanding of what needs to be done as evidenced by the detailed planning in the technical basis reviews and in various documents that were reviewed. The IRT also concluded that the RTP process is reasonable and includes a reasonable set of requirements to support an RTP decision.

In addition, two teams assisted with the financial analysis. The teams included members from TRW, Inc. and Lockheed Martin Energy Systems. One of the teams conducted risk modeling and analysis; the other team reviewed the enabling assumptions and evaluated the overall programmatic risk. The results of these reviews are described in Section 8.0 of this Management Assessment.

\subsection{PHASE 1B WASTE FEED DESCRIPTION, OPERATING SCENARIOS, AND PROCESSING SUMMARY}

This section describes the waste feed envelopes, operating scenario, feed selection and sequencing, waste transfers to support the operating scenario, and staging strategy and batch cycle time. The ability of the PHMC team to supply the feed is analyzed and recommendations to enhance Phase $1 \mathrm{~B}$ are also discussed.

\subsection{WASTE FEED ENVELOPES}

The Privatization Requests for Proposal defines four feed envelopes (A, B; C, and D) to demonstrate private contractor processing capabilities. These envelopes are summarized in Table 3. 
Table 3. Waste Feed Envelopes Summary.

\begin{tabular}{|l|l|}
\hline Envelope & \multicolumn{1}{|c|}{ Description } \\
\hline A & $\begin{array}{l}\text { Waste that tests the production capacity and fission-product removal efficiency. Produces a final } \\
\text { product in which waste loading is limited by sodium. }\end{array}$ \\
\hline B & $\begin{array}{l}\text { Similar to } \mathrm{A}, \text { except that final product waste loading is limited by minor component } \\
\text { concentrations }\left(\mathrm{Cl}, \mathrm{Cr}, \mathrm{F}, \mathrm{PO}_{4}, \text { or } \mathrm{SO}_{4}\right) \text {. These minor components may stress the private } \\
\text { contractor facilities' offgas system. }\end{array}$ \\
\hline C & $\begin{array}{l}\text { Contains organic complexants which keep }{ }^{90} \mathrm{SR} \text { and TRU in solution. May require organic } \\
\text { destruction. }\end{array}$ \\
\hline $\mathrm{D}$ & $\begin{array}{l}\text { Contains insoluble solids which are classified as } \mathrm{HLW} \text { waste. The envelope approximates solids } \\
\text { content in three existing double-shell tanks: } \mathrm{AZ}-101, \mathrm{AZ}-102 \text {, and AY-102 (including C-106). }\end{array}$ \\
\hline
\end{tabular}

HLW = high-level waste.

LAW = low-activity waste.

TRU = transuranic.

\subsection{OPERATING SCENARIO}

The Phase $1 \mathrm{~B}$ operating scenario includes the activities necessary to mix, transfer, stage, condition, deliver, process, and interim store or dispose of waste. The scope of this operating scenario includes:

- $\quad$ Retrieve, prepare, and deliver both HLW and LAW feed

- $\quad$ Return to the DST system of entrained solids and separated ${ }^{90} \mathrm{Sr} /$ transuranic (TRU) from the private contractors

- Return of immobilized low-activity waste (ILAW) to the PHMC team for disposal

- Return of immobilized high-level waste (IHLW) to the PHMC team for interim storage

- Receipt and management of waste from facility clean out, salt well pumping, and retrieval of SSTs.

This operating scenario was developed based on the steps listed below.

a. Applicable requirements from the privatization contracts and major enabling assumptions were identified.

b. Specific DSTs that contain waste that would be used to satisfy the quantity and sequence requirements of the waste feed envelopes were identified and the sequence of batches was established. 
c. Delivery dates and process durations for each batch were determined to assure a steady. supply of feed to the private contractors at the assumed processing rates.

d. Specific waste transfers and processing activities needed to prepare and deliver each batch of feed were established.

e. Volume and timing of the ILAW, IHLW, entrained solids, and separated ${ }^{90} \mathrm{Sr} / \mathrm{TRU}$ being returned from the private contractors were estimated based on contract requirements and flowsheet considerations.

f. The operating scenario was checked for consistency with contract requirements and enabling assumptions.

Requirements and major enabling assumptions that may significantly influence the operating scenario are listed in Tables 4 and 5; respectively. If these assumptions are changed, a schedule risk may develop that would require further analysis. The operating scenario was developed using these requirements and assumptions. Comparisons of each requirement with the operating scenario demonstrates that the requirement is supported by the detailed plans and expected system performance.

Table 4. Major Requirements that Influence the Operating Scenario.

\begin{tabular}{|l|l|}
\hline \multicolumn{1}{|c|}{ Major requirement } & \multicolumn{1}{c|}{ Area influenced } \\
\hline Envelope definitions for LAW and HLW feed & LAW feed; HLW feed \\
\hline Order quantities for LAW and HLW feed & $\begin{array}{l}\text { LAW feed; HLW feed } \\
\text { IHLW interim storage } \\
\text { ILAW disposal }\end{array}$ \\
\hline Minimum batch sizes for LAW and HLW feed & LAW feed; HLW feed \\
\hline Minimum system capacity demonstration & $\begin{array}{l}\text { LAW feed; HLW feed } \\
\text { IHLW interim storage } \\
\text { ILAW disposal }\end{array}$ \\
\hline $\begin{array}{l}\text { Schedule for proof-of-concept (processing minimum order quantities) } \\
\text { and extension period (processing combined maximum order quantities) }\end{array}$ & $\begin{array}{l}\text { LAW feed; HLW feed } \\
\text { IHLW interim storage } \\
\text { ILAW disposal }\end{array}$ \\
\hline Minimum WOL in IHLW & IHLW interim storage \\
\hline Maximum ILAW package volume per unit of LAW feed delivered & ILAW disposal \\
\hline
\end{tabular}

HLW $=$ high-level waste. IHLW $=$ immobilized high-level waste.
ILAW = immobilizedlow-activity waste.

$\mathrm{LAW}=$ low-activity waste.
WOL $=$ waste oxide loading. 
Table 5. Major Enabling Assumptions That Influence the Operating Scenario.

\begin{tabular}{|c|c|}
\hline Major enabling assumption & Area influenced \\
\hline $\begin{array}{l}\text { Two LAW Facilities } \\
\text { One HLW Facility }\end{array}$ & $\begin{array}{l}\text { LAW feed; HLW feed } \\
\text { IHLW interim storage } \\
\text { ILAW disposal }\end{array}$ \\
\hline Maximum order quantities will be processed & $\begin{array}{l}\text { LAW feed; HLW feed } \\
\text { IHLW interim storage } \\
\text { ILAW disposal }\end{array}$ \\
\hline $\begin{array}{l}\text { HLW processing rate of } 0.164 \mathrm{MT} \mathrm{NVOL/day} \mathrm{(averaged} \mathrm{over} \mathrm{each} \\
\text { individual feed batch). }\end{array}$ & $\begin{array}{l}\text { HLW feed } \\
\text { IHLW interim storage }\end{array}$ \\
\hline $\begin{array}{l}\mathrm{LAW} \text { processing rate of } 2.0 \mathrm{MT} \mathrm{Na} / \text { day/contractor (averaged over each } \\
\text { individual feed batch). }\end{array}$ & $\begin{array}{l}\text { LAW feed } \\
\text { ILAW disposal }\end{array}$ \\
\hline IHLW is delivered at the minimum allowable WOL. & IHLW interim storage \\
\hline $\begin{array}{l}591 \text { Canisters ( } 3: 0 \text { meters) allocated for IHLW storage including } \\
\text { IHLW, dry cesium, and nonroutine HLW per vault. }\end{array}$ & IHLW interim storage \\
\hline $\begin{array}{l}\text { The private contractors achieve the values of ILAW package volume } \\
\text { per unit of LAW feed delivered stated in Brown (1996). }\end{array}$ & ILAW disposal \\
\hline $\begin{array}{l}\text { LAW feed will be qualified (certified) in the source tank when } \\
\text { necessary to support the assumed processing rates. }\end{array}$ & LAW feed \\
\hline $\begin{array}{l}\text { The tank space projections in the Operational Waste Volume } \\
\text { Projections (Strode and Boyles 1997) remain valid. }\end{array}$ & LAW feed; HLW feed \\
\hline $\begin{array}{l}\text { The entire feed qualification process takes no longer than } 85 \text { days for } \\
\text { LAW. feed and } 68 \text { days for HLW. }\end{array}$ & LAW feed; HLW feed \\
\hline $\begin{array}{l}\text { New ILAW disposal facilities can be authorized, designed, constructed, } \\
\text { and ready to operate in a } 3.5 \text { year period. }\end{array}$ & ILAW disposal \\
\hline
\end{tabular}

Brown, N. R., 1996, LLW Product Waste Loading Assumptions for the TWRS Process Flowsheet, (internal memorandum to R. M. Orme, April 23), U.S. Department of Energy, Richland, Washington.

Strode, J. N., and V. C. Boyles, 1997, Operational Waste Volume Projection, HNF-SD-WM-ER-029, Rev. 23, prepared by Lockheed

Martin Hanford Corporation for Fluor Daniel Hanford, Inc., Richland, Washington.

$\mathrm{HLW}=$ high-level waste $. \quad \mathrm{MT}=$ metric tons.

IHLW = immobilized high-level waste.

ILAW $=$ immobilized low-activity waste.

$\mathrm{Na}=$ sodium.

$\mathrm{LAW}=$ low-activity waste.

NVOL $=$ novolatile oxides less sodium and silicon.

WOL $=$ waste loading oxide.

\subsection{FEED SELECTION AND SEQUENCING}

\subsubsection{Low-Activity Waste Feed}

The two primary sources of LAW feed are tanks containing supernatant liquid or supernatant liquid on top of sludge, and tanks containing salt slurry or supernatant liquid on top 
of salt slurry. In the first case, the supernatant liquid is the material of interest; in the second case, the combined supernatant liquid and salt slurry after dissolution of the solids is the material of interest. The material of interest is called the "targeted waste."

The strategy for staging LAW feed uses two intermediate staging tanks. The overall schematic is depicted in Figure 8. The targeted waste is retrieved and transferred to the staging tanks (AP-102. and AP-104), blended and adjusted as needed, and verified to meet the envelope requirements. The feed is transferred to the private contractors' feed tanks (AP-106 and AP-108) when the private contractors are ready to receive the next batch. When staging tanks are emptied, the waste for the next feed batch is retrieved.

Figure 8. Low-Activity Waste Feed Schematic.

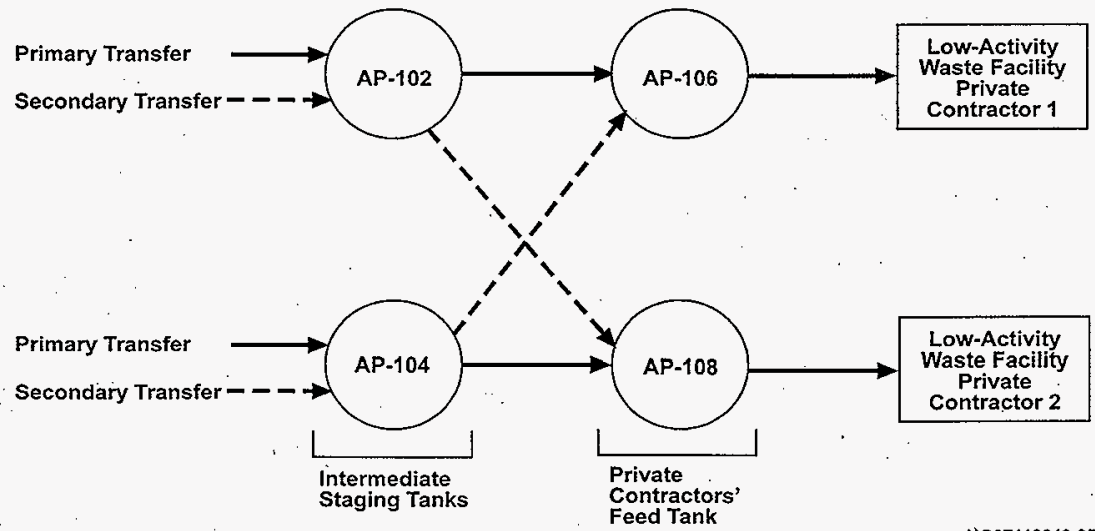

HG97110249.65 $2021-8$

The LAW feed envelope (A-C) composition requirements were developed such that the limits would encompass the majority of the DST waste. The composition of the targeted waste in each DST was evaluated by using the best available tank characterization data. The dilution water needed to retrieve and transfer the waste and the dissolution and/or precipitation of solids after dilution was taken into account to estimate compositions for the "targeted waste." The composition of the targeted waste in each DST was then compared with the envelope limits and each tank was classified in the appropriate envelope. In addition, laboratory process testing is being performed to confirm the dissolution behavior, transport properties, and composition of the targeted waste that is planned for delivery as feed.

The DSTs that will be used to provide the feed were selected and the processing sequence established to be consistent with the order quantities and envelope limits specified in the privatization contracts. The selected sequence considered logistics whenever there was 
flexibility in meeting the contract requirements. These included consideration of how close the targeted feed was to the envelope limits, ease of retrieval, integration of tank usage with the operation waste volume projections, emptying source tanks promptly, processing more dilute waste first to free up tank space more quickly, and simplification of construction project designs and schedules.

Table 6 shows the source of feed for each feed batch, the volume, and quantity of feed available in the source tank, the dilution water requirements, and pre-staging tank (when required).

Processing times for each batch were estimated from the size of the feed batch and the assumed processing rates.

Table 7 summarizes the available quantities of LAW feed and delivery quantities to the private contractors. The operating scenario is adequate to meet the minimum order quantities of envelopes $\mathrm{A}, \mathrm{B}$, and $\mathrm{C}$, and can deliver up to the combined maximum order quantity.

\subsubsection{High-Level Waste Feed}

The creation of HLW feed envelope $D$ specifications was determined using process knowledge and analytical data from four source tanks: AZ-101, AZ-102, AY-102, and C-106. Therefore, these tanks were selected as source tanks for Phase 1B HLW feed. Tank C-104 was selected to provide the additional material needed to satisfy the maximum order quantity.

The composition of the conditioned sludge from each HLW source tank was determined using the best available tank characterization and process test (sludge washing) data. The Environmental Simulation Program ${ }^{1}$ was used to simulate the in-tank sludge washing process. The sludge washing process was tailored with the objective of satisfying the envelope D composition limits. Laboratory process testing is planned to confirm the chemical behavior, physical properties, transport properties, and composition of the separated sludge.

The processing sequence was established by integrating existing project and retrieval activities with the operational waste volume projections. For example, tank AZ-101 was selected as the first source of HLW feed to take advantage of the mixer pumps that have already been installed by Project W-151, tank AZ-101 Waste Retrieval System.

The sludge in tanks AZ-101 and AZ-102 will be conditioned and delivered directly from their source tanks to the HLW immobilization facility. Sludge from tank C-106 will be retrieved into tank AY-102 and then transferred to AZ-101 when tank space is available. The blend will be conditioned in AZ-101 and then delivered to the HLW immobilization facility. As soon as the

${ }^{1}$ Environmental Simulation Program is a Registered Trademark of OLI Systems, Inc. 
conditioned sludge is removed from tank $\mathrm{AY}-102$, sludge from tank $\mathrm{C}-104$ will be retrieved into tank AY-102, transferred to AZ-102 (when tank space is available), conditioned, and delivered to the HLW immobilization facility.

Table 8 summarizes the available quantities of HLW feed and delivery quantities to the private contractors. The operating scenario will meet the minimum order quantity of envelope $D$ and can deliver up to the maximum order quantity.

Columns 2 through 5 of Table 8 indicate the HLW batch number, the HLW source tanks, the quantity and volume of each batch, and the pre-stage tank where applicable. The approximate timing is based on the batch size (quantity) and the assumed immobilization average processing rate of $0.164 \mathrm{MT}$ of equivalent nonvolatile oxides excluding sodium and silicon per day.

\subsection{WASTE TRANSFERS TO SUPPORT THE OPERATING SCENARIO}

The waste transfers required to support the operating scenario were determined from the feed sequence and required processing activities. Tank Farms will also continue to make other transfers not directly related to staging of feed. These other transfers are required to support ongoing waste management activities such as receipt of facility waste, salt well pumping, SST retrieval and operation of the 242-A Evaporator. Both the feed staging and waste management transfers were analyzed to ensure the demands on tank space will not exceed available DST space.

Table 6 also shows the approximate timing for the retrieval, staging, and delivery of each LAW feed batch along with the quantity and volume delivered to each private contractor. Figure 9 shows the transfers that directly support the retrieval, staging and delivery of the first three batches of LAW feed for each contractor. Figure 10 shows the sequence and approximate timing of the transfers that are required to retrieve, stage and deliver the first batch of LAW feed.

Table 8 shows the approximate timing for the retrieval, separation, and delivery of the HLW feed batches along with the quantity and volume delivered.

Figure A-1 (the transfer routing in Appendix A) shows the transfer routes for each batch of LAW and HLW feed. 

Table 7. Comparison of Low-Activity Waste and High-Level Waste Feed Quantities with Contract Requirements.

\begin{tabular}{|c|c|c|c|c|c|c|}
\hline \multirow[t]{2}{*}{ Envelope } & \multirow[t]{2}{*}{ Units } & \multicolumn{5}{|c|}{ Totals for Two Contractors } \\
\hline & & $\begin{array}{l}\text { Minimum envelop } \\
\text { order quantity }\end{array}$ & & $\begin{array}{l}\text { Base case } \\
\text { elivered quan }\end{array}$ & & $\begin{array}{l}\text { Maximum envelope } \\
\text { order quantity }\end{array}$ \\
\hline A & $\mathrm{MTNa}$ & 5,200 & & 5,399 & $\leq$ & 9,800 \\
\hline B & $\mathrm{MTNa}$ & 200 & & 234 & $s$ & 2,000 \\
\hline $\mathrm{C}$ & $\mathrm{MTNa}$ & 200 & & 4,578 & $\leq$ & 4,800 \\
\hline$A+B+C^{\prime}$ & $\mathrm{MTNa}$ & & $\approx$ & $10,200^{2}$ & $\leq$ & $10,200^{1}$ \\
\hline $\mathrm{D}$ & MT NVOL & 245 & & 465 & $s$ & 465 \\
\hline
\end{tabular}

'There is a combined maximum order quantity limit for envelopes $A, B$, and $C$ that is iess than the sum of the individual maximum order quantities.

${ }^{2}$ Rounded off

- LAW $=$ low-activity waste.

NVOL $=$ nonvolatile oxides less sodium and silicon.

$\mathrm{Na}=$ sodium.

$\mathrm{MT}=$ metric tons.

\subsection{STAGING STRATEGY AND BATCH CYCLE TIME.}

The staging strategy for LAW requires that the staging tanks (AP-102 and AP-104) be essentially empty before the next batch of feed is retrieved. The next feed batch must be ready before the private contractor finishes processing the previous batch. This means that the amount of time available for staging (retrieval, transfer, and adjustment) a feed batch is constrained by the time required to process the previous feed batch.

The estimated times required for staging feed batches were evaluated. All feed batches can be prepared within the available time. Table 9 depicts a summary of the evaluation for envelope A feed. Figure 11 compares the required time with the processing time as established in the operating scenario. Batch 7 was assumed to be prequalified in the source tank (tank AN-107) because no subsequent blending or processing is required. Batch 7 contains supernatant liquid from AN-107. The feed for batch 7 will be prequalified in the source tank using mass balances to determine the delivered composition if expected process improvements do not enable more rapid turnaround time.

\subsection{IMMOBILIZED LOW-ACTIVITY WASTE}

The ILAW portion of Phase $1 \mathrm{~B}$ will receive, transport, and dispose of the ILAW produced by the private contractors. Disposal facilities will be constructed, truck and transport container systems will be procured, and these systems will be operated to dispose of the waste. 
Project W-465 is scheduled to modify four existing grout vaults before startup of the private contractor's immobilization plant. These vaults provide capacity for a minimum of 5,000 ILAW packages with flexibility to increase that capacity by approximately 50 percent through additional stack height.

New disposal facilities will be constructed by Project W-520 to provide follow-on capacity. These projects will provide ILAW disposal capacity for the remainder of Phase $1 \mathrm{~B}$ and Phase 2. Figure 12 shows that Project W-465 will operate a minimum of 3 years until additional disposal capacity is required. At least one new disposal module, along with its supporting roads, water, and electrical infrastructure will be needed to receive ILAW packages at the end of that 3-year period.

Production estimates indicate that a total of four to five packages per day will be transported from the private contractors to the disposal facilities. Peak transport rates could be as high as nine packages per day. Time and motion estimates indicate that each round trip will require approximately 3.5 hours per package. These estimates allow for the completion of radiation surveys, loading, transport, unloading, receipt radiation surveys, and return to the original location. The number of operating shifts, operating trucks, and disposal vault cranes is flexible enough to accommodate day-to-day variations in private contractor production rates.

Space requirements will be strongly influenced by private contractor startup date, production rates, and glass waste loading. The volume of ILAW that each contractor is allowed to return is limited by the glass waste loading. Waste loading limits are defined in the privatization contracts as: " "... for every gram-mole of sodium provided to the contractor in waste envelopes $A$ and $C$, the contractor may produce up to $100 \mathrm{~cm}^{3}$ of ILAW product, based on external dimensions of the package $\left(250 \mathrm{~cm}^{3}\right.$ for envelope $\left.B\right) \ldots$. These values are shown as contract maximums in Figure 12. DOE guidance was used as the planning basis (Brown 1996). The contract provides incentives to reduce the total number of waste packages (i.e., increased waste loadings).

Figure 12 compares the baseline system ILAW disposal capacity with the base case operating scenario. The expected ILAW can be accommodated; however, additional stacking . height and/or acceleration of Project W-520 disposal facility schedule may be needed for certain operating scenarios.

The "bounding case" assumes that the TWRS contractor delivers the worst possible combination of feed (as much envelope B waste as possible as soon as possible) that is allowed by the contract and that the contractor always produces the maximum permitted ILAW for the delivered feed. This case is not considered reasonable for planning purposes because the waste required to deliver this amount of envelope $B$ feed is not projected to be available in the DST system during Phase 1B.

The "base case operating scenario" is based on the specific feed planned to be delivered to the private contractors and conditions (Brown 1996). This curve shows that additional stacking 
Table 8. High-Level Waste Source Tanks and Feed Batches.

\begin{tabular}{|c|c|c|c|c|c|c|c|c|c|c|c|c|c|c|c|c|c|}
\hline \multirow{2}{*}{ Envelope } & \multirow{2}{*}{ Batch } & \multicolumn{3}{|c|}{ Available feed ${ }^{3}$} & \multirow{2}{*}{$\begin{array}{l}\text { Sluicing } \\
\text { receiver }\end{array}$} & \multirow{2}{*}{$\begin{array}{l}\text { Washing and } \\
\text { staging tank }\end{array}$} & \multicolumn{5}{|c|}{ Approximate timing ${ }^{b}$} & \multicolumn{2}{|c|}{$\begin{array}{l}\text { Total feed delivered from } \\
\text { source tank }\end{array}$} & \multicolumn{2}{|c|}{$\begin{array}{l}\text { Feed delivered } \\
\text { per batch }\end{array}$} & \multicolumn{2}{|c|}{$\begin{array}{l}\text { Feed delivered to } \\
\text { immobilization }\end{array}$} \\
\hline & & $\begin{array}{c}\text { Source } \\
\text { tank }\end{array}$ & $\begin{array}{l}\text { Quantity }^{c} \\
\text { (MT) }\end{array}$ & $\begin{array}{l}\text { Volume } \\
\text { (ML) }\end{array}$ & & & $\begin{array}{c}\text { Begin } \\
\text { sluicing }\end{array}$ & $\begin{array}{c}\text { Begin pre- } \\
\text { stagings }\end{array}$ & \begin{tabular}{|c|}
$\begin{array}{c}\text { Begin } \\
\text { conditioning }\end{array}$ \\
\end{tabular} & $\begin{array}{l}\text { Batch } \\
\text { ready }\end{array}$ & $\begin{array}{c}\text { Batch } \\
\text { delivered }\end{array}$ & $\begin{array}{l}\text { Quantity } \\
\text { (MT) }\end{array}$ & $\begin{array}{c}\text { Volume } \\
\text { (ML) }\end{array}$ & $\begin{array}{l}\text { Quantity } \\
\text { (MT) }\end{array}$ & $\begin{array}{l}\text { Volume } \\
\text { (ML) }\end{array}$ & $\begin{array}{c}\text { Delivery } \\
\text { time (days) }\end{array}$ & $\begin{array}{c}\text { Process } \\
\text { time (days) }\end{array}$ \\
\hline \multirow{12}{*}{ D } & 1 & \multirow{2}{*}{ AZ-101 } & \multirow{2}{*}{96.4} & \multirow{2}{*}{0.18} & \multirow{2}{*}{-} & \multirow{2}{*}{$A Z-101$} & \multirow{2}{*}{ - } & \multirow{2}{*}{ - } & \multirow{2}{*}{$10 / 2000$} & \multirow{2}{*}{$8 / 2001$} & $5 / 2002$ & \multirow{2}{*}{86.8} & \multirow{2}{*}{1.06} & 43.4 & 0.53 & 1 & 264 \\
\hline & 2 & & & & & & & & & & $2 / 2003$ & & & 43.4 & 0.53 & 1 & 264 \\
\hline & 3 & \multirow{2}{*}{$A Z-102$} & \multirow{2}{*}{161.5} & \multirow{2}{*}{0.39} & \multirow{2}{*}{ - } & \multirow{2}{*}{ AZ-102 } & \multirow{2}{*}{ - } & \multirow{2}{*}{.-} & \multirow{2}{*}{$4 / 2002$} & \multirow{2}{*}{$2 / 2003$} & $11 / 2003$ & \multirow{2}{*}{97.0} & \multirow{2}{*}{1.10} & 48.5 & 0.55 & 1 & 295 \\
\hline & 4 & & & & & & & & & & $8 / 2004$ & & & 48.5 & 0.55 & 1 & 295 \\
\hline & 5 & \multirow{5}{*}{$A Y-102$} & & & & & & & & & $6 / 2005$ & & & 32.9 & 0.49 & 1 & 200 \\
\hline & 6 & & 37.5 & 0.08 & & & & & & & $1 / 2006$ & $\cdot$ & & 32.9 & 0.49 & 1 & 200 \\
\hline & 7 & & & & AY-102 & $A Z-101$ & $10 / 1998$ & $6 / 2003$ & $6 / 2003$ & $4 / 2004$ & $7 / 2006$ & 165 & 2.45 & 32.9 & 0.49 & 1 & 200 \\
\hline & 8 & & 156.3 & 0.75 & & & & & & & $2 / 2007$ & & & 32.9 & 0.49 & 1 & 200 \\
\hline & 9 & & & & & & & & & & $8 / 2007$ & & & 32.9 & 0.49 & 1 & 200 \\
\hline & 10 & & & & & & & & & & $3 / 2008$ & & & 46.9 & 0.54 & 1 & 285 \\
\hline & 11 & C-104 & 386.0 & 1.12 & AY-102 & AZ-102 & $7 / 2004$ & $7 / 2005$ & $7 / 2005$ & $5 / 2006$ & $12 / 2008$ & 117 & 1.35 & 46.9 & 0.54 & 1 & 285 \\
\hline & 12 & & & & & & & & & & $10 / 2009$ & & & 23.5 & 0.27 & 1 & 143 \\
\hline
\end{tabular}

"The "Available Feed" volumes and quantities have not been reduced to account for the waste hells that will be left behind in the source tanks, pre-staging tanks, or staging tanks.
oAll dates are subject to change within the contract and ICD limits. All dates and durations are based on a 0.164 MT NVOL/day processing rate (averaged over each individual feed batch).

"All dates are subject to change within the contract and ICD limits. All dates and durations are based on a 0.164 MT NVOUdday processing rate (aver
The "Ouantity" of feed is defined as the mass of equivatent nonvolatile oxides excluding sodium and silicon, as defined in the Privatization contracts

(1) The current baseline has allocated an additional 6 months for the confirmation of "Processing times are based on an assumed immobilization facility processing rate of $0.164 \mathrm{MT}$ of equivalent nonvolatile oxides per day.

$\mathrm{ICD}=$ Interface Control Document

$\mathrm{ML}=$ million liters

$\mathrm{NVOL}=$ nonvolatil 
Figure 9. Diagram of Staging Transfers in Chronological Order (Low-Activity Waste Batches 1-3) - Baseline.

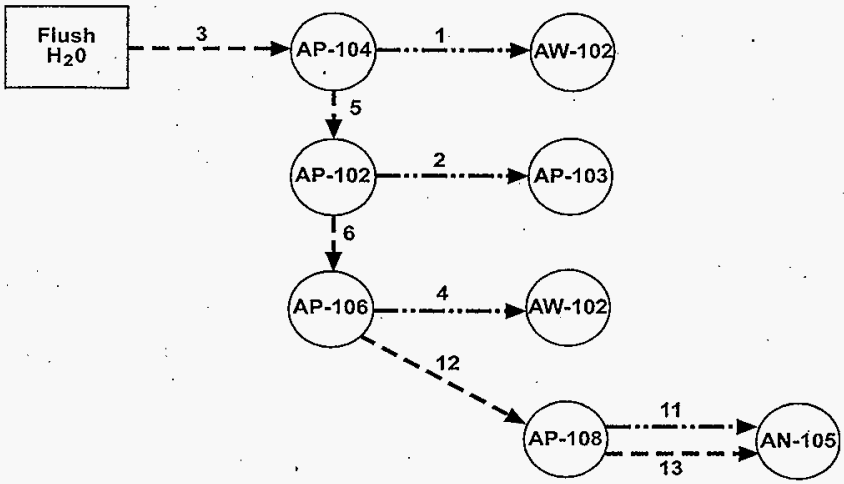

Batch 1

(Ënvelope A)

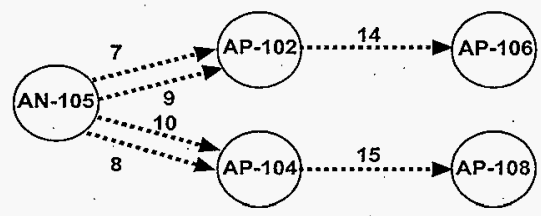

Batch 2

(Envelope A)

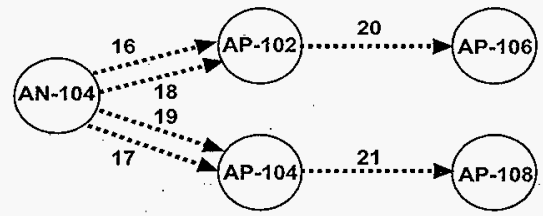

Batch 3

(Envelope A)

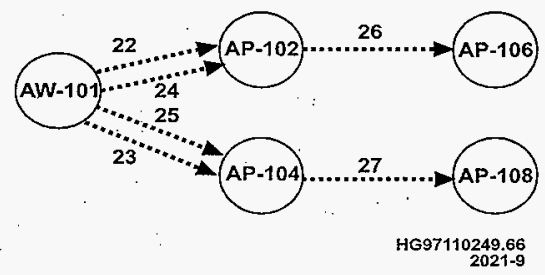

\footnotetext{
- - Flush

-...- Evaporator Staging

1 Chronological order of transfers
} 
Figure 10. Staging Transfers for the First Low-Activity Waste Feed Batch.

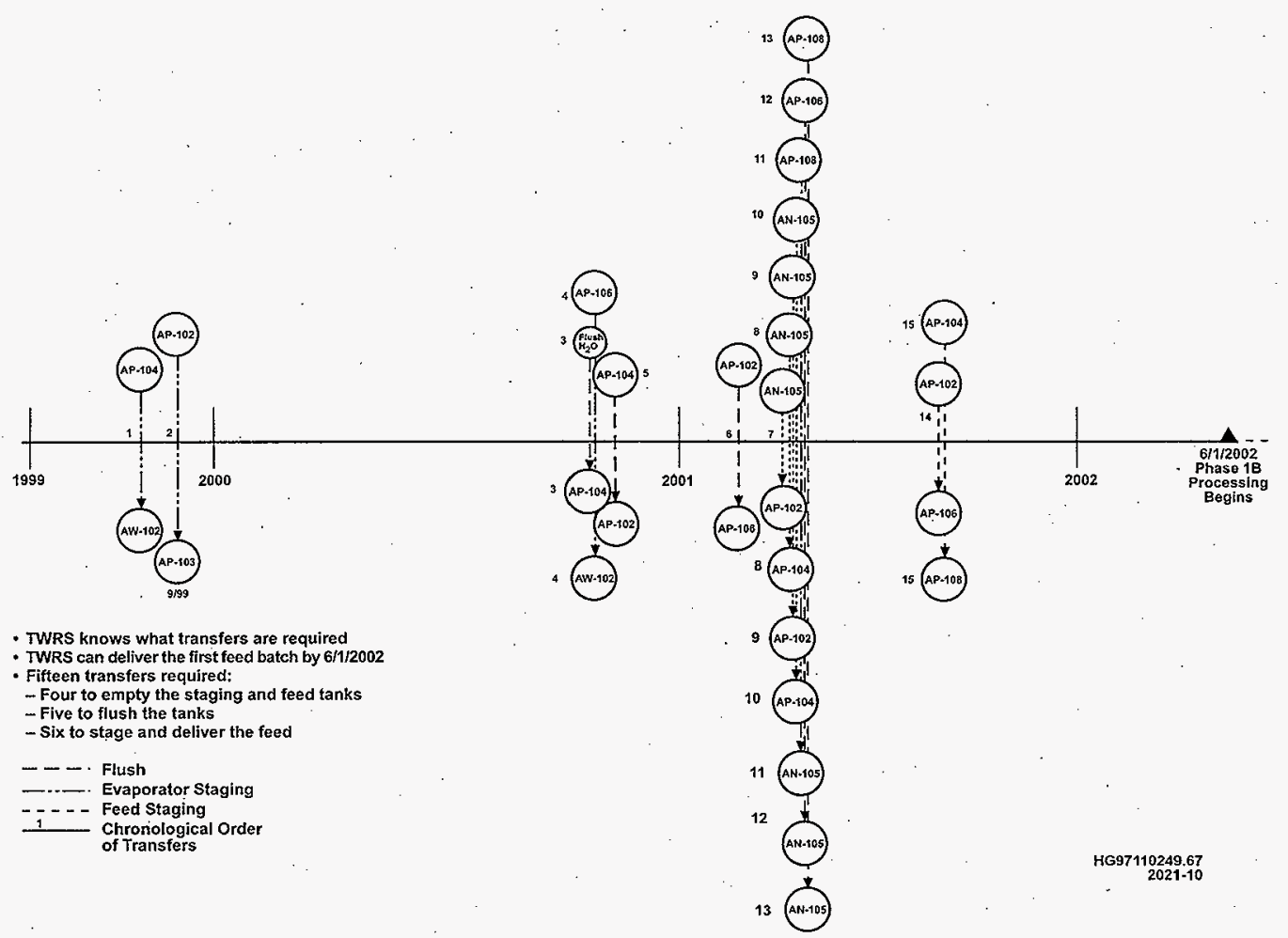

- TWRS knows what transfers are required

TWRS can deliver the first feed batch by 6/1/2002

Fifteen transfers required:

- Four to empty the staging and feed tanks

Five to flush the tanks

or Staging

eed Staging

Chroriological Orde

(AN-105 
Figure 11. Retrieval, Staging, and Feed Qualification Times.

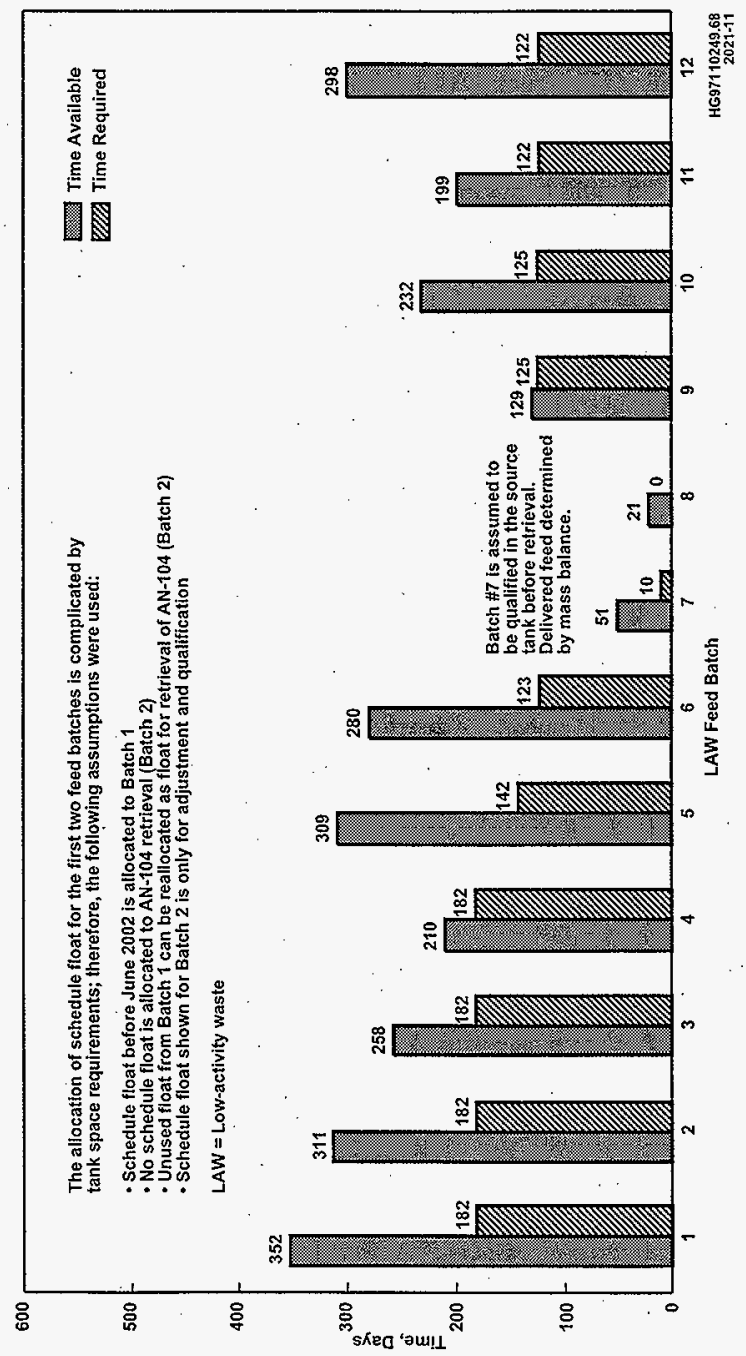


Table 9. Typical Low-Activity Waste Feed Delivery Batch Cycle Time for Envelope A.

\begin{tabular}{|c|c|}
\hline Activity & Time (days) \\
\hline $\begin{array}{l}\text { Mobilize and retrieve LAW from source tank } \\
\text { - } \quad \text { Decant supernatant with in-line dilution } \\
\text { - } \quad \text { Add dilution water and dissolve solids in-tank } \\
\text { - } \quad \text { Mix tank and take process control samples } \\
\text { Decant dissolved solids }\end{array}$ & 69 \\
\hline $\begin{array}{l}\text { Adjust staged feed as required } \\
\text { - Mix tank and take process control samples } \\
\text { - } \quad \text { Select feed adjustment and document } \\
\text { Add chemical (shim) solution }\end{array}$ & 28 \\
\hline $\begin{array}{l}\text { Feed qualification } \\
\text { - Mix tank and obtain feed qualification samples } \\
\text { (for PHMC team and archive) } \\
\text { - } \quad \text { Provide samples to private contractor } \\
\text { - } \quad \text { Prolyze samples and issue sample qualification report } \\
\text { Provide feed qualification/certification report to private contractors }\end{array}$ & 85 \\
\hline TOTAL DURATION* & 182 \\
\hline
\end{tabular}

*From emptying AP-102 and AP-104 of the previous batch to when the next batch is ready for delivery to the private contractors.

LAW $=$ low-activity waste.

height or accelerated startup of Project W-520 disposal facilities may be needed. Factors such as the ramp-up production of the plants and actual throughput rates add uncertainty in the projected ILAW receipts over time. The disposal requirements will be reevaluated as private contractor processing rates are finalized.

The "lower planning basis" is not a strict lower limit, but a reasonable estimate of the lowest ILAW receipts over time. It assumes that the PHMC team provides the private contractors the minimum amount of envelope $B$ feed and that the private contractors process the minimum and combined maximum order quantities at the slowest rates that satisfy the terms of the contracts.

\subsection{IMMOBILIZED HIGH-LEVEL WASTE}

The IHLW portion of Phase $1 \mathrm{~B}$ is to receive, transport, and store the IHLW, returned cesium and packaged nonroutine $\mathrm{HLW}$ produced by the private contractors. Storage facilities will be constructed, truck and transport container systems will be procured, and these systems will be operated to store the waste until a deep geological repository for HLW is ready. 
Figure 12. Immobilized Low-Activity Waste Disposal Capacity Versus Demand.

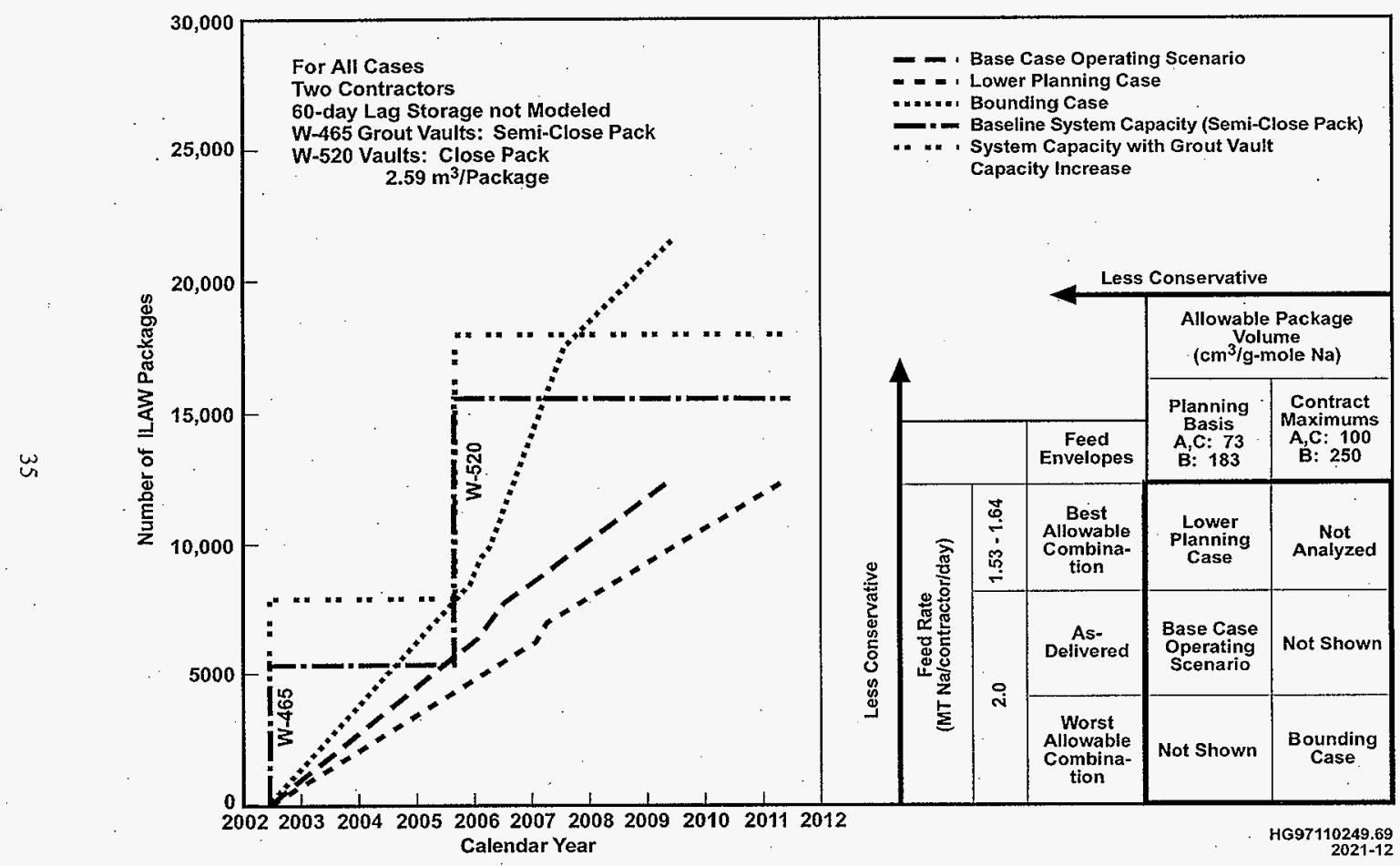

\footnotetext{
ILAW = Immobilized low-activity waste

MT = Metric ton

$\mathrm{Na}=$ Sodium
} 
Project W-464 will modify vaults 2 and 3 of the Canister Storage Building to allow storage of the Immobilized HLW packages, dry cesium, or nonroutine HLW from the private contractors. These products are required to be delivered in a canister suitable for storage in the Canister Storage Building. Vaults 2 and 3 of the Canister Storage Building will be modified to hold 880 of the $4.5-\mathrm{m}$ canisters or 1320 of the $3-\mathrm{m}$ canisters. Figure 13 shows that an estimated 1182 canisters $(3-\mathrm{m})$ will be needed for the immobilized HLW. The remaining 138 positions are available for returned dry cesium and nonroutine HLW. The number of dry cesium and nonroutine HLW canisters are being coordinated through ICD discussions with the private contractors. Current engineering estimates indicate that approximately $96 \%$ of the total available space will be utilized by the combination of immobilized HLW, dry cesium, and nonroutine HLW.

The volume of IHLW that the private contractor is allowed to return is limited by the minimum waste oxide loading imposed by the contracts. Figure 13 compares the baseline system IHLW storage capacity with the base case operating scenario. Sensitivity cases are not shown because the entire IHLW storage capacity is brought on-line at the start of Phase IB processing (Project W-464). The required IHLW storage capacity was determined by using the maximum order quantity and minimum $25 \mathrm{wt} \%$ nonvolatile oxides excluding sodium and silicon waste oxide loading. This represents an upper bound on required IHLW storage capacity.

The maximum canister handling capacity is estimated at 1.35 canisters per day. The canister handling rate is determined by the package transporter from the private facilities to the IHLW storage facility, as well as the unloading system and facility cranes and control installed in the modified Canister Storage Building.

The key consideration for IHLW storage availability is coordination of construction and operating schedules with spent nuclear fuels. This interface is being actively managed by the PHMC team to accommodate recent changes for spent nuclear fuels and to maintain a June 2002 capability for accepting IHLW.

\subsection{RECOMMENDATIONS}

The operating scenario was developed and analyzed using applicable requirements from the privatization contracts and establishing assumptions for key information that is not currently available.

The operating scenario was found to deliver appropriate quantities and composition of LAW and HLW feed at the proper time; to provide tank space to accept the returned "entrained solids and separated ${ }^{90} \mathrm{Sr} / \mathrm{TRU}$;" to provide adequate capability for the disposal of ILAW; to provide adequate storage capability for the interim storage of IHLW; and to manage these activities within existing tank space. 
Figure 13. Immobilized High-Level Waste Interim Storage Capacity Versus Demand.

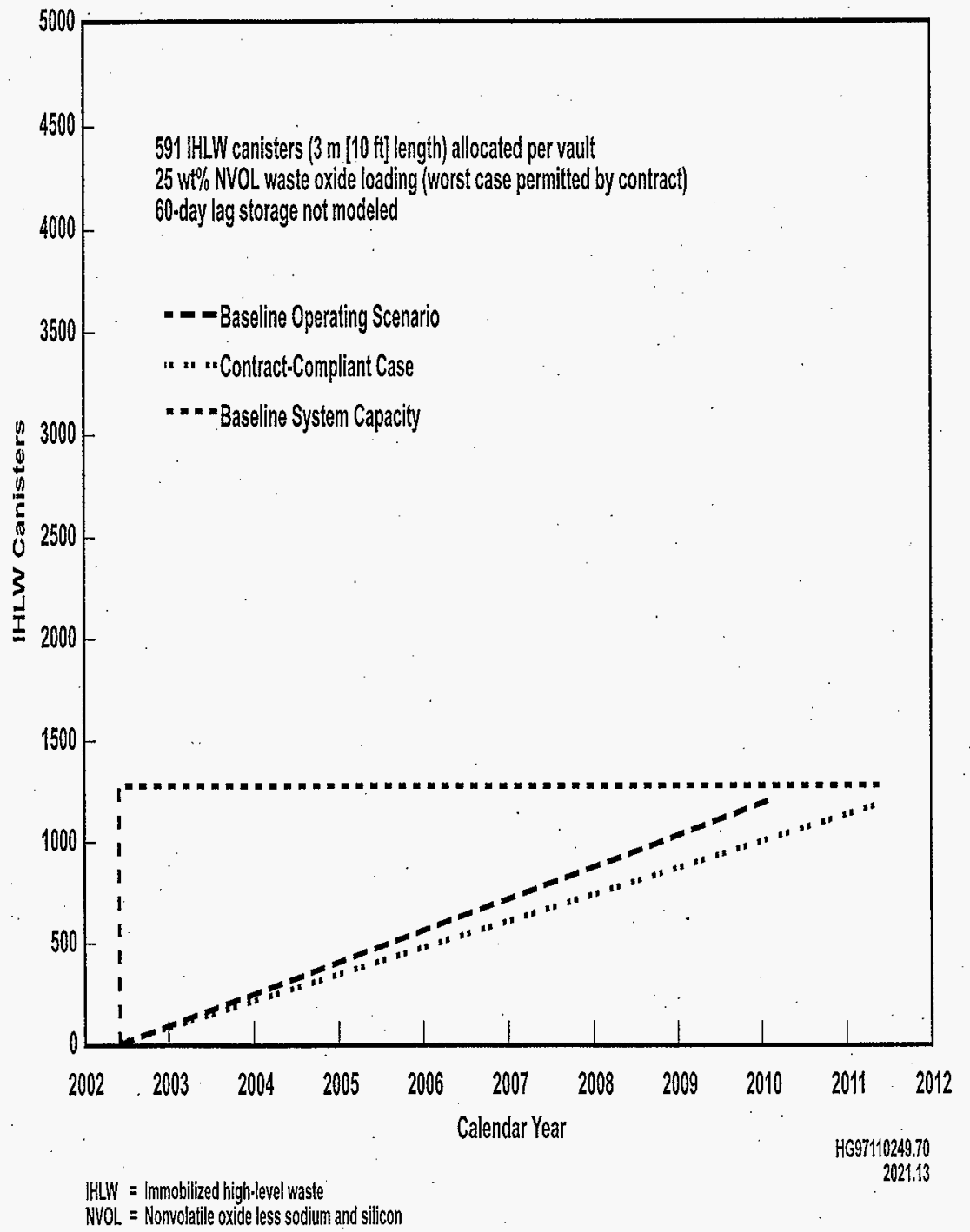


It is recommended that DOE consider the direct transfer of existing waste in tanks AP-106 and AP-108 to the private contractors. This would reduce the complexity of the feed transfer operations and result in significant cost savings.

The other recommendations listed below should increase the robustness of the feed delivery system and reduce risks and the overall cost of Phase $1 \mathrm{~B}$.

- Impose a minimum time duration between the completion of the delivery of one feed batch and the waste transfer date for the following batch. This provides the RI/TWRS contractor with sufficient time to stage feed, regardless of high processing rates and/or small feed batches.

- Allow the PHMC team to complete delivery of the feed batch that reaches a minimum order quantity even if this means that the minimum order quantity will be exceeded. This enables the TWRS contractor to free up usable DST tank space as fast as possible by allowing full tanks of waste to be retrieved and delivered and avoids having to deal with "odd-lot" sized batches. The contracts imply that the minimum order quantities need to be delivered exactly - no more and no less. This recommendation will provide a range to deliver slightly more than the minimum order quantities to ensure that the minimum order quantities are met.

- $\quad$ Reduce the minimum size of the first $L A W$ feed batch. Reducing the minimum size of the first feed batch will reduce the risk that the first feed batch will be short and the need (and associated costs) to blend or shim the first feed batch to satisfy this limit.

- Minimize the number of analytes and physical properties to be analyzed for envelope $D$ to include only those components that are considered significant to the performance of the immiobilization process. This will minimize time durations to complete laboratory analysis, avoid laboratory instrumentation upgrade costs, and provide additional schedule contingency.

- Develop a compensation model for processing off-specification feed and include this provision in the privatization contracts. This provides RL with options that reduce the overall cost and schedule impacts of ensuring that delivered feed satisfies the envelopes. If a feed batch cannot be certified as meeting the appropriate envelope limits, this provides RL with the option to deliver as-is and avoid potential schedule impacts and/or contract disputes.

- $\quad$ Refine the LAW envelope limits for aluminum, sulfate, total organic carbon, TRU, and ${ }^{90} \mathrm{Sr}$. Also, modify the current definition of envelope $\mathrm{D}$ (and the expanded design basis), specifically for the maximum concentrations of aluminum and silver. 
These refinements increase the robustness of the operating scenario by providing greater flexibility in selecting and staging feed, reducing the potential need to blend and/or shim feed and allow better use of existing feed sources. The risks of not delivering the proper composition of feed are reduced along with the potential costs to $\mathrm{RL}$ from risk mitigation.

- Include a new combined minimum order quantity for envelopes $A, B$, and $C$. Reduce the minimum order quantity of envelope $A$. These two recommendations taken together provide flexibility in selecting feed that satisfies the minimum order quantities of envelopes $\mathrm{A}, \mathrm{B}$, and $\mathrm{C}$ and provide additional flexibility in scheduling construction projects.

It is recognized that these recommendations may require contract negotiation. The complete discussion of these recommendations is provided in HNF-SD-WM-SP-012, Tank Waste Remediation System Operation and Utilization Plan (Kirkbride et al. 1997).

\subsection{EQUIPMENT UPGRADES AND NEW FACILITIES TO SUPPORT PHASE 1B}

This section discusses the upgrades and new facilities required to support mobilization of the wastes, delivery to the private contractor via the intermediate staging tanks, and eventual storage and disposal of the immobilized products. As discussed above, the feed delivery requirements were analyzed and used to select tanks that contained the desired feed envelope wastes. The equipment in these tanks was then evaluated to determine upgrade requirements to mobilize the waste. In parallel, the associated transfer pipelines were evaluated to determine upgrades required to move the wastes to feed staging tanks. Finally, private contractor processing rates were used to determine the timing and scope of storage and disposal facilities for immobilized wastes.

The results of these evaluations were used to define requirements for new or modified systems required to support Phase 1B. Table 10 lists four projects that will be completed in FY 1998. These projects provide two new cross site transfer lines, improve the aging waste tank ventilation system, provide equipment to remove wastes from tank $\mathrm{C}-106$, and provide mixer pumps for tank $A Z-101$.

To meet the rest of the Phase 1B feed delivery, infrastructure upgrades, and waste disposal requirements, seven construction projects were developed as shown in Table 11.

Three of these projects are designed to mobilize wastes and supply the waste feed to the private contractors. Projects W-211, Initial Tank Retrieval Systems; W-314, Tank Farm Restoration and Safe Operations; and W-TBD include the addition of mixer pumps (and other 
- Table 10. Summary of Projects that will be Completed in Fiscal Year 1998.

\begin{tabular}{|l|l|l|l|}
\hline \multicolumn{1}{|c|}{ Project no./title } & \multicolumn{1}{|c|}{ Scope } & \multicolumn{1}{|c|}{ Schedules } & Costs (TPC) \\
\hline $\begin{array}{l}\text { W-058 } \\
\text { Cross-Site Transfer } \\
\text { System }\end{array}$ & $\begin{array}{l}\text { Provide two new transfer lines from 200 } \\
\text { West to 200 East, including associated } \\
\text { mechanical equipment and } \\
\text { instrumentation }\end{array}$ & $\begin{array}{l}\text { The Project will be } \\
\text { completed in } \\
\text { FY 1998 }\end{array}$ & TPC \$49.3 million \\
\hline $\begin{array}{l}\text { W-030 } \\
\text { Tank Farm } \\
\text { Ventilation } \\
\text { Upgrade }\end{array}$ & $\begin{array}{l}\text { Install new ventilation systems on the } \\
\text { Aging Waste Tanks, AZ and AY tank } \\
\text { farms }\end{array}$ & $\begin{array}{l}\text { The Project will be } \\
\text { completed in FY } \\
1998\end{array}$ & TPC \$47.9 million \\
\hline $\begin{array}{l}\text { W-320 } \\
\text { Tank C-106 } \\
\text { Sluicing }\end{array}$ & $\begin{array}{l}\text { Provides equipment and facilities } \\
\text { modifications to mobilize contents of } \\
\text { tank C-106 and transfer contents to tank } \\
\text { AY-102 }\end{array}$ & $\begin{array}{l}\text { Construction will } \\
\text { be completed and } \\
\text { sluicing initiated in } \\
\text { FY 1998 }\end{array}$ & TPC \$85:6 million \\
\hline $\begin{array}{l}\text { W-151 } \\
\text { Tank 101-AZ } \\
\text { Waste Retrieval } \\
\text { System }\end{array}$ & $\begin{array}{l}\text { Provides two mixer pumps and ancillary } \\
\text { equipment for mobilizing the sludge in } \\
\text { tank AZ-101 }\end{array}$ & $\begin{array}{l}\text { The Project will be } \\
\text { completed in FY } \\
1998\end{array}$ & TPC $\$ 27.7$ million \\
\hline
\end{tabular}

$F Y=$ fiscal year.

$T P C=$ total project cost.

equipment necessary to mobilize the feed), transfer systems to move the feed to the staging tanks, and add in-tank sludge washing capability. Project W-TBD was scoped to include additional transfer systems and other equipment not yet included in projects W-211 and W-314.

Three additional projects provide the transfer, storage, and disposal facilities for the immobilized product. Project W-465, ILAW Disposal Project, provides facilities for receipt and disposal of ILAW in modified grout vaults. Project W-520, the follow-on for Project W-465, provides additional disposal capacity for the balance of the Phase 1B ILAW product. Project W-464, Interim IHLW Storage, provides facilities for receipt and interim storage of IHLW products, returned cesium, and nonroutine IHLW.

Project W-519, Privatization Phase 1 Infrastructure, provides utilities (raw and potable water, electrical and effluent transfer lines), roads and site development work to support the infrastructure needs of the private contractors for Phase 1B.

The overall summary schedule of construction project activities necessary to support Phase 1B is shown in Figure 14. 
Table 11. Summary of the Projects, Scope, Schedules and Costs.

\begin{tabular}{|c|c|c|c|}
\hline Project no./title & Scope & Schedules & Costs (TPC) \\
\hline $\begin{array}{l}\text { W-211 } \\
\text { Initial Tank } \\
\text { Retrieval System }\end{array}$ & $\begin{array}{l}\text { Mobilization and transfer } \\
\text { systems for waste retrieval in } \\
\text { ten tanks }\end{array}$ & $\begin{array}{l}\text { FY } 1996-2005 \\
\text { First feed tank AN-105, Design } \\
\text { start October 1997, Operational } \\
\text { March } 2001\end{array}$ & $\$ 229$ million \\
\hline $\begin{array}{l}\text { W-314 } \\
\text { Tank Farm } \\
\text { Restoration }\end{array}$ & $\begin{array}{l}\text { Provides infrastructure } \\
\text { upgrades to the tank farms }\end{array}$ & $\begin{array}{l}\text { Phase } 1 \text { FY 1997-2000 } \\
\text { Phase } 2 \text { 2001-2024 }\end{array}$ & $\begin{array}{l}\text { Phase } 1 \$ 70 \\
\text { million } \\
\text { Phase } 2 \$ 230 \\
\text { million }\end{array}$ \\
\hline W-TBD & $\begin{array}{l}\text { Sludge washing capability in } \\
\text { AZ-101 and four additional } \\
\text { DST retrieval and transfer } \\
\text { systems }\end{array}$ & $\begin{array}{l}\text { AZ-101 portion FY } 1998-2001 \\
\text { W-211 follow-on FY 1998-2004 }\end{array}$ & $\$ 76$ million \\
\hline $\begin{array}{l}\text { W-464 } \\
\text { Interim High- } \\
\text { Level Waste } \\
\text { Storage }\end{array}$ & $\begin{array}{l}\text { Receipt and interim storage of } \\
\text { the IHLW. }\end{array}$ & $\begin{array}{l}\text { Design start FY } 2000 \\
\text { Construction FY } 2001 \\
\text { Operational June } 2002\end{array}$ & $\$ 42$ million \\
\hline $\begin{array}{l}\text { W-465 } \\
\text { Low-Activity } \\
\text { Waste-Disposal }\end{array}$ & $\begin{array}{l}\text { Receipt and disposal of ILAW } \\
\text { in modified grout vaults }\end{array}$ & $\begin{array}{l}\text { Design Start FY } 2000 \\
\text { Construction FY } 2001 \\
\text { Operational June } 2002\end{array}$ & $\$ 43$ million \\
\hline $\begin{array}{l}\text { W-519 } \\
\text { Privatization } \\
\text { Phase 1 } \\
\text { Infrastructure }\end{array}$ & $\begin{array}{l}\text { Provide Infrastructure for } \\
\text { private vendors }\end{array}$ & FY 1998- 2001 & $\$ 36$ million \\
\hline $\begin{array}{l}\text { W-520 } \\
\text { LAW Disposal }\end{array}$ & $\begin{array}{l}\text { Balance of Phase I ILAW } \\
\text { disposal capacity }\end{array}$ & $\begin{array}{l}\text { Design Start FY } 2001 \\
\text { Construction FY } 2003 \\
\text { Operation FY 2004/2005 }\end{array}$ & $\$ 84$ million \\
\hline
\end{tabular}

$\mathrm{DST}=$ double-shell tank.

$F Y=$ fiscal year.

IHLW = immobilized high-level waste.

ILAW = immobilized low-activity waste.

$T B D=$ to be determined.

$\mathrm{TPC}=$ total project cost.

\subsection{PROJECT MANAGEMENT}

DOE selected the PHMC team, recognizing their commercial expertise would speed the transition to a maintenance and integration contract and improve project management. The contractors on the PHMC team have extensive fixed-price contracting experience. Both Fluor Daniel, Inc., and Lockheed Martin Corporation successfully complete fixed price contracts in the global market. Cogema, Inc./SGN Company, the parent company of Numatec Hanford, Inc., owns, constructs, and operates nuclear facilities that encompass the complete nuclear fuel cycle 
(including vitrification and disposal). Duke Power constructs and operates major nuclear power stations and has a reputation for excellence in operations. Lockheed Martin Corporation is a

$\$ 35$ billion annual sales corporation that has been successfully completing fixed-price contracts for decades. The majority of Lockheed Martin Corporation business is fixed-price contracts with the U.S. Department of Defense. These fixed-price contracts are generally multi-million (and billion) dollar weapons systems procurements and aircraft projects that involve development and deployment of state-of-the-art technologies to new products. Lockheed Martin Corporation's theme of mission success is based on completing products on time and within budget. The PHMC team has brought this expertise to the Hanford Site and is in the process of restructuring the entire project management culture, policies, and procedures to parallel those successfully used in commercial enterprises. Figure 15 provides top-level summary of the systems engineering technical basis approach that the PHMC team is applying to TWRS Projects.

Upon assumption of responsibility for TWRS, LMHC conducted management assessment of all projects. LMHC found that projects generally lacked elements required for success. Project technical cost and schedule baselines were built on an incomplete set of technical safety and operational requirements. A full set of life cycle functional requirements (such as constructability, operability, maintainability; reliability, etc.) were lacking. The planned Authorization Basis for the projects was not consistent with the tank farms Authorization Basis. Clear lines of communication and accountability were weak. This lack of specificity resulted in scope creep, schedule delays, and cost overruns. As these projects were corrected and rebaselined, lessons learned were developed and applied to TWRS planning and management processes.

Since the PHMC team takeover, LMHC, with the assistance of its Fluor Daniel Hanford, Inc. (FDH), project direction team, has strived to establish the fixed-price contract mentality, patterned after U.S. Department of Defense models, within its management team. This commercial-based, systems engineering approach will be used for Phase 1B TWRS Projects. LMHC is well into the process of bringing the TWRS' culture into line with best commercial practices. Using established financial controls, recognized project management tools, contract reform, demonstrated leadership, and employee involvement is producing results. A recent successful example. was the near $\$ 50$ million cross-site transfer pipeline. Completion of this project was on time and on budget. Lockheed Martin Corporation has brought the expertise of one of the largest fixed price contracting and project management teams in the world to TWRS. This expertise will assure the TWRS Projects are completed on time and within budget.

\subsection{SUMMARY PROJECT STATUS}

The physical system required to support Phase 1B by the TWRS organization in the 200 Area has been defined and is understood. The evaluation of the existing system against the required system has identified the gaps and vulnerabilities. Several projects which are in various 
Figure 14. Summary Schedule of Construction Project Activities to Support Phase 1B.

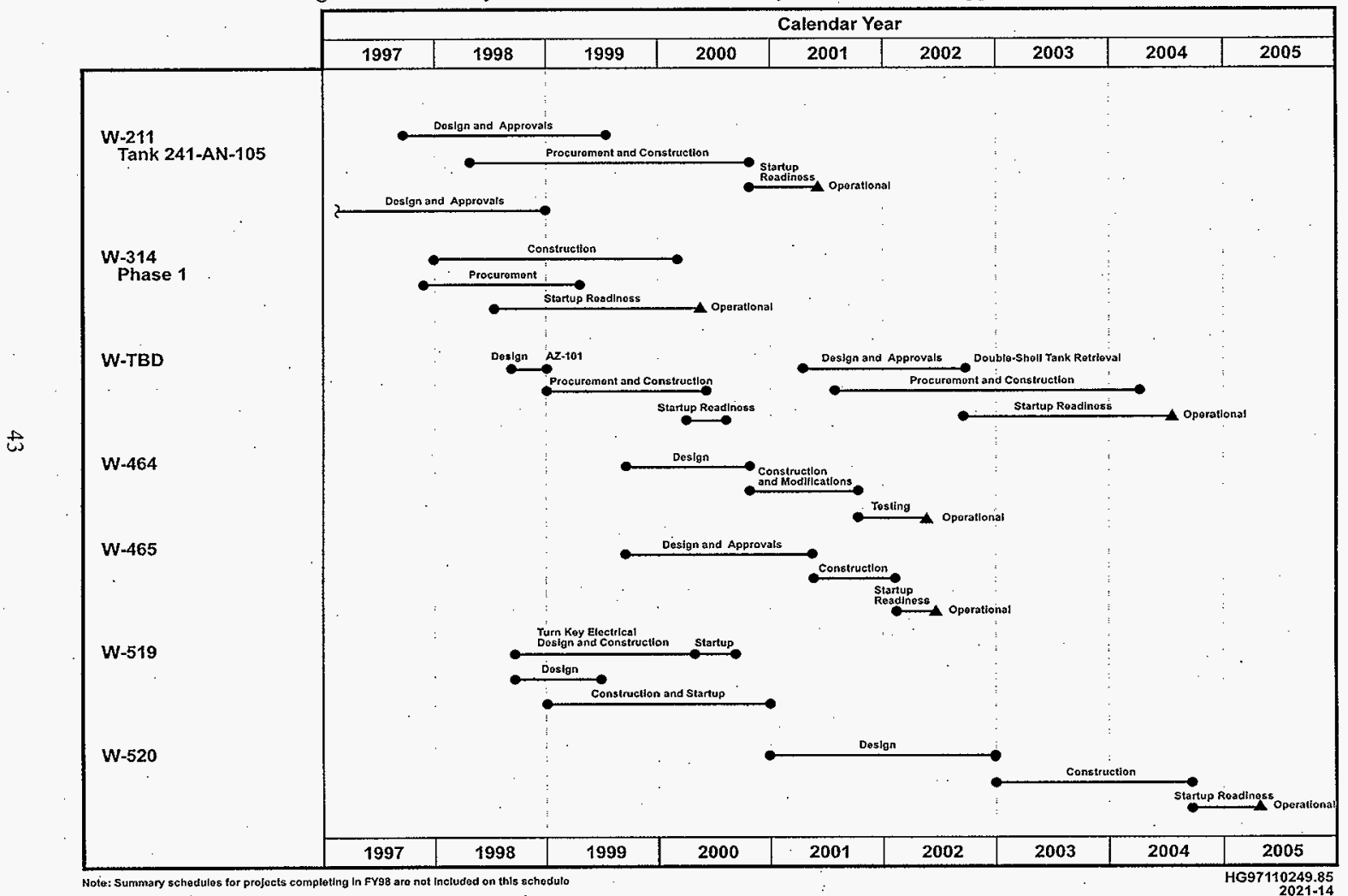


stages of completion will provide the new or modified systems to eliminate the gaps and vulnerabilities. The design, procurement, construction, testing, and startup activities for the projects will be accomplished in time to support the June 2002 date. Key risks have been identified and will be managed.

\subsection{OPERATIONS SUPPORT TO PHASE 1B RETRIEVAL}

The TWRS Project has a mature and compliant Operations organization. Operations, maintenance and engineering, and other support staff are fully trained. Operations' line management is responsible and accountable for TWRS facilities and safety. Management systems and procedures are in place and ready to support Phase 1B. Activities similar to those necessary to support Phase $1 \mathrm{~B}$ are conducted routinely. The maturity of the Operations and programs are supported by favorable trends in performance indicators, conclusions, and trends from a series of independent assessments and operations readiness reviews.

The TWRS Project has rigorous safety and licensing policies and procedures that are patterned after nuclear industry requirements and comply with the applicable DOE orders. The Authorization Basis has been upgraded with the approval of the HNF-SD-WM-BIO-001, Tank Waste Remediation System Basis for Interim Operation (BIO) (FDH 1997). The BIO (FDH 1997) provides the framework for future amendments to authorize the retrieval and storage activities. Commercial industry evaluation techniques were used to develop a comprehensive hazard analysis. Based on hazards, postulated accidents were analyzed and controls were implemented to protect the public and onsite workers. A Plant Review Committee provides overviews of operations and engineering activities and maintains configuration management with the Authorization Basis. Changes to procedures, modifications, and selected off-normal events are evaluated to ensure the activities are within the authorized safety envelope. PHMC team policies and procedures define the methods to evaluate and determine training requirements and to train and qualify the staff. These programs comply with DOE Order 5480.20A, Personnel Selection, Qualification, and Training at DOE Nuclear Facilities.

Figure 16 illustrates the overall process used to plan and complete work in TWRS facilities. This system is patterned after the general guidance contained in the DNFSB Technical Report Number 16 on "Integrated Safety Management" (DNFSB 1997). The work scope for each activity is clearly defined, and requirements for safe performance are developed by integrating the safety elements. Next the hazards associated with performing the work are analyzed and controls to mitigate or prevent the hazards are developed and included in the work package. The work is conducted in accordance with the work package; improvement suggestions are fed back into the preparation of the future work packages. This integrated safety management system is described in greater detail in the BIO (FDH 1997); WHC-SD-WM-PLN-114, TWRS Safety Management Plan (Popielarczyk 1996); and HNF-SD-WM-HSP-002, Tank Farm Health and Safety Plan (Mickle 1995). These documents contain or reference the associated implementing procedures. 
Figure 15. Top Level Summary of Technical Basis for Operations.

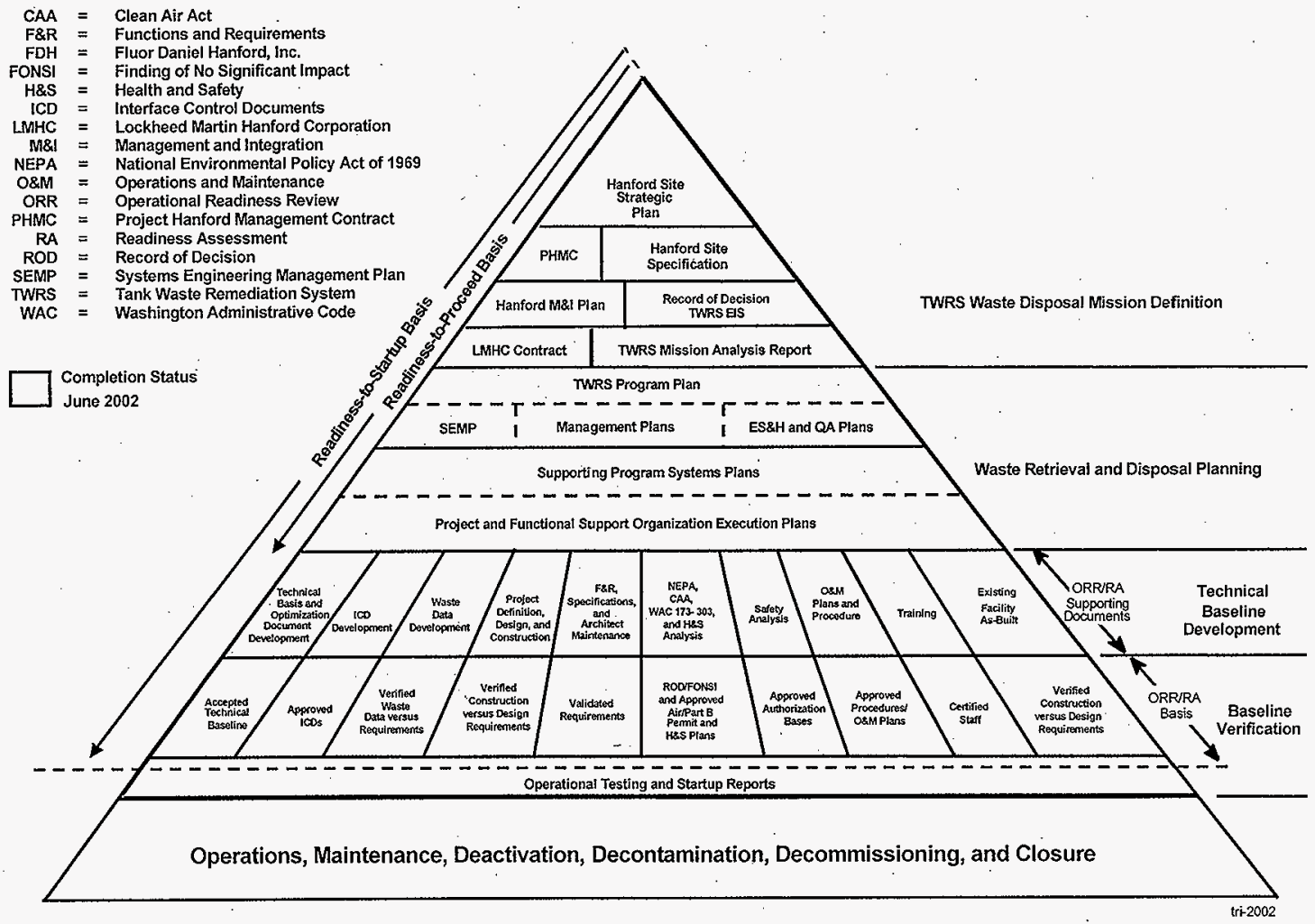


Figure 16. Process Used to Plan and Complete Work.

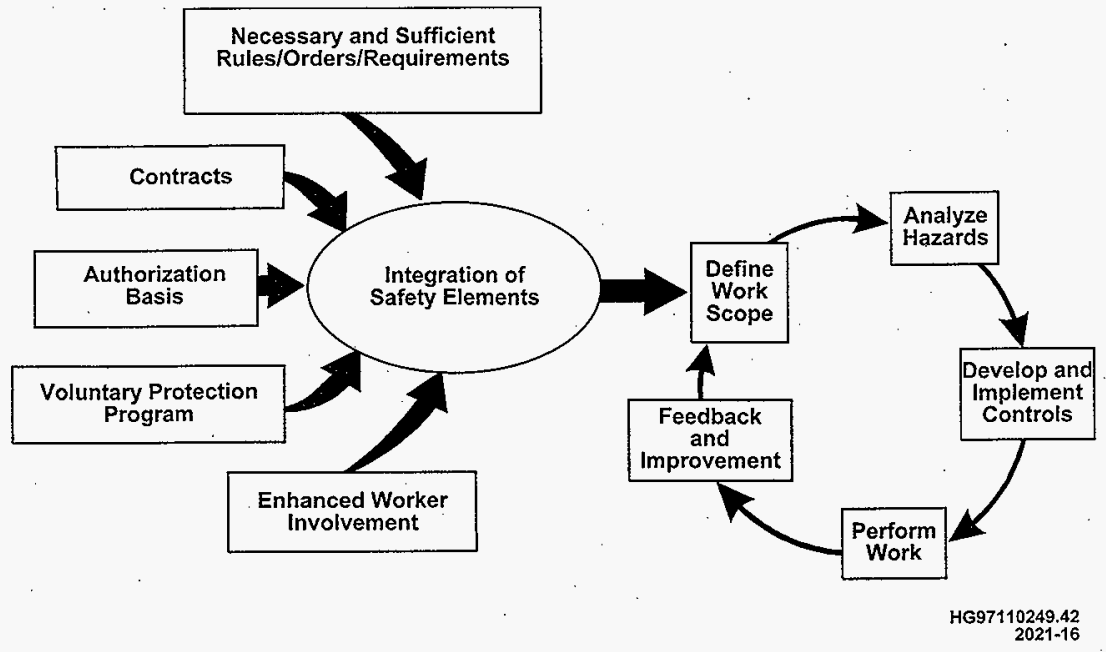

The integrated safety management process described above has proven very effective in getting a large volume of work completed safely in a timely manner. Figure 17 shows the volume of work completed in a typical year and the low rate of off-normal events. On an annual. basis, nearly 3,500 separate work packages are completed. Over the last four quarters, the average number of work packages completed has increased from 729 to 996 per quarter. The number of occurrences associated with this work is low and the rate of occurrences is decreasing.

Trends in industrial and occupational safety performance are also improving. Figure 18 shows the trends in lost work case rates and recordable injuries. Over the last year, the lost workday case rate has been reduced by 68 percent (below FY 1996 rates) from 0.72 to 0.23 per 200,000 man hours. These rates are well below the national average for similar work and are

also below the goals and actual performance levels set by the Institute of Nuclear Power Operations (INPO) for nuclear utilities. The INPO goals for lost work day case rates for the year Readiness Reviews evaluated the readiness of procedures, training and qualification programs, personnel staffing levels and knowledge, safety documentation, facility systems, management 2000 are 0.4 per 200,000 hrs [Institute of Nuclear Power Operations 1996 Annual Report, (Institute of Nuclear Power Operations (INPO) 1996)]. 
Figure 17. Volume of Work and Low Rate of Off Normal Events.

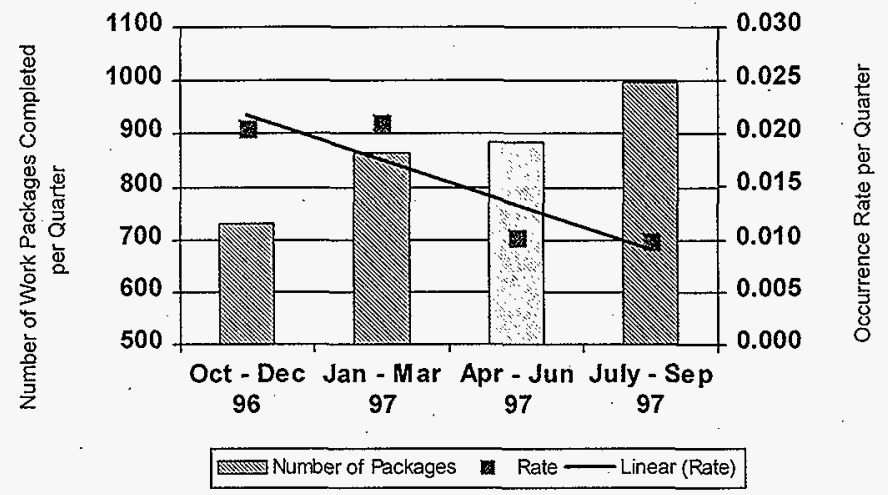

Figure 18. Trends in Lost Work. Day Case Rates and Recordable Injuries.

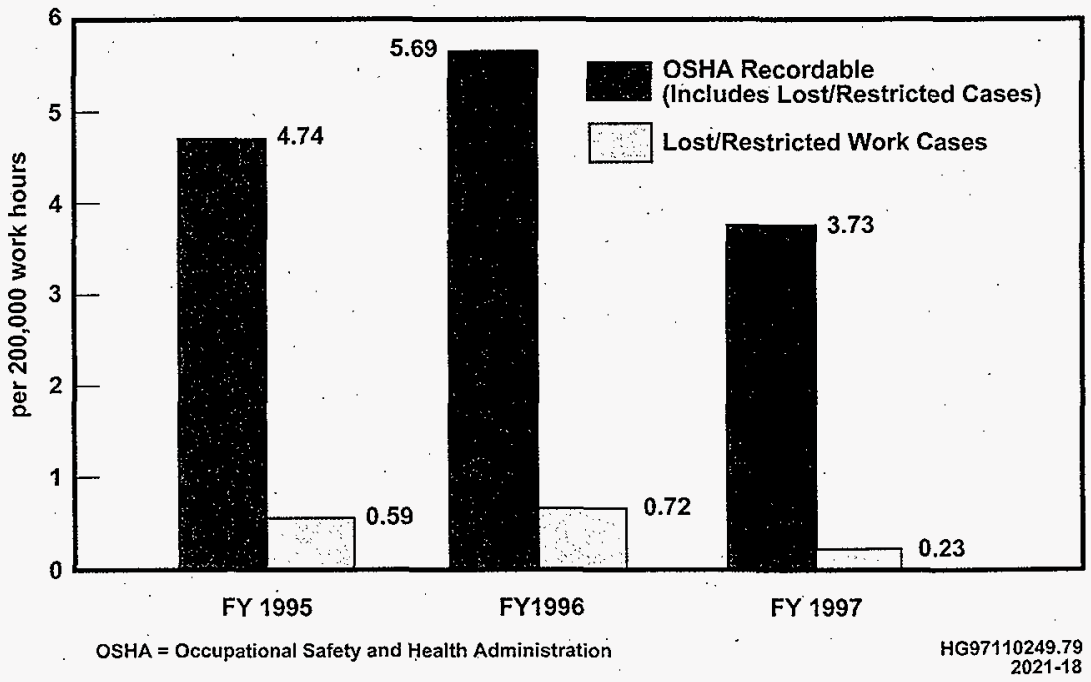


Physical appearance and compliance with Occupational Health and Safety Act of 1970 requirements at TWRS facilities have also improved substantially. In late 1996 frequent compliance inspections were implemented. Multi-disciplined teams of craft workers, operators, and engineers inspect facilities weekly. TWRS facilities are checked every three months. Whenever possible, deficiencies are corrected on the spot. Over the last year, 6,135 deficiencies were identified and 77 percent were corrected. These inspections and associated corrective actions encourage employee involvement and continuous improvements.

LMHC organized the TWRS Project around the work scope necessary to support the cleanup mission. Previously stovepiped projects and programs were eliminated in favor of more efficient project teams supported by strong functional groups. These project-driven teams focus on mission completion while the functional groups provide consistency across the TWRS Project. LMHC is also reengineering the sitewide business and financial, work control, and project management systems. The reengineered systems will be placed in service in FY 1998 and 1999 and will provide systems equivalent to the best of those used in commercial businesses.

Since mid-1996, the Hanford Site Facility Evaluation Board has completed three separate performance-based assessments of TWRS facilities. These independent assessments meet the DOE Order requirements and are repeated periodically at frequencies commensurate with the performance ratings. These assessments are designed to provide a thorough, accurate, and independent measure of performance effectiveness. The assessment teams and processes are structured and conducted similar to the performance-based evaluations conducted by INPO and by the U.S. Navy Nuclear Program. The assessments are based on direct observations in ten assessments areas: Facility Organization and Administration, Operations, Radiological Control, Engineering, Maintenance, Occupational Safety and Health, Training, Emergency Preparedness, Environmental Programs, and Quality Assurance. The assessments include a critical examination of work processes, records, and management systems. The conclusions from all three assessments were that the TWRS facilities were operated safely. Especially significant is the steady improvement in Facility Evaluation Board ratings. Table 12 provides a summary of the Facility Evaluation Board ratings and the associated grading criteria.

In November 1997, a Lockheed Martin Corporate team of nine experienced auditors conducted a rigorous independent environmental, safety, and health audit of TWRS facilities and programs. The team assessed 35 environmental safety and health program areas. The overall rating was satisfactory, which is indicative of a compliant environmental safety and health program.

Finally, Operations Readiness Reviews, based on the requirements in DOE Order 425.1, were conducted before placing new systems in operation and to ensure major changes in the Authorization Basis were satisfactorily implemented. Recently completed successful readiness reviews include rotary mode core sampling, and BIO implementation. These Operations systems, emergency preparedness and drills, test programs, conduct of operations, DOE order compliance, environmental safety and health programs, and independent review systems. Each . 
Table 12. Summary of Facility Evaluation Board Assessments of Tank Waste Remediation System Facilities.

\begin{tabular}{|l|l|l|l|}
\hline & \multicolumn{1}{|c|}{$\begin{array}{c}\text { August 1996 } \\
\text { SST }\end{array}$} & $\begin{array}{c}\text { April 1997 } \\
\text { DSTs and } \\
\text { Characterization }\end{array}$ & $\begin{array}{c}\text { November 1997 } \\
\text { SST }\end{array}$ \\
\hline Organization and Administration & 3 & 3 & 3 \\
\hline Operation & 3 & 3 & 3 \\
\hline Radiological Controls & 4 & 4 & 3 \\
\hline Engineering & 3 & 3 & 3 \\
\hline Maintenance & 3 & 3 & 3 \\
\hline Occupational Safety \& Health & 4 & 2 & 2 \\
\hline Training & 3 & 2 & 2 \\
\hline Emergency Preparedness & 3 & 3 & 3 \\
\hline Environmental Protection & 4 & 3 & 2 \\
\hline Quality Assurance & 4 & 3 & 3 \\
\hline Overall Summary & 4 & 3 & 3 \\
\hline
\end{tabular}

FEB Grade Definitions

1. Excellent: Standards of performance are very high. The minimum requirements are exceeded in most areas.

2. Meets Expectations: Standards of performance are high. The minimum requirements and management expectations are met.

3. Meets Minimum Requirements: Standards of performance are acceptable. The minimum requirements are met.

4. Below Expectations: Standards of performance are marginal and need to be raised.

5. Significantly below Expectations: Standards of performance are not acceptable and need to be raised significantly.

$\mathrm{DST}=$ double-shell tank.

$\mathrm{FEB}=$ Facility Evaluation Board.

SST $=$ single-shell tank.

of the Operations Readiness Reviews concluded that the equipment, supporting facilities, personnel, and procedures were in place to safely proceed with operations. 


\subsection{MAJOR RISKS AND UNCERTAINTIES}

The PHMC team has identified the primary uncertainties and risks that must be managed to successfully meet the feed delivery requirements for the Phase 1B feed delivery and disposal mission. The risks are described in detail in Zimmerman (1998). Some of the more significant risks include the following.

- DOE may contract with the private contractors for a higher feed rate than the TWRS Project Contractor can initially deliver. In addition, private contractor contracts for Phase $1 B$ may deviate from specifications in the Phase $1 A$ contracts or from planning assumptions made by the TWRS Project Contractor. The proposed contractual changes will be reviewed. Any impacts on planning assumptions or schedules will be evaluated.

- Any significant changes in rates of saltwell pumping or waste generation by other facilities could limit the ability to transfer waste within the DST System. The TWRS Project has very little uncommitted DST space to use for the feed staging activities between now and the operation of the LAW immobilization facilities. The PHMC team planning indicates that a feasible feed delivery approach can be implemented. However, there will be very little flexibility to respond to losses of usable DST space caused by unforseen circumstances (e.g., tank leak, additional safety or conduct of operations restrictions, or significant increases or delays in waste additions from salt well pumping or facility deactivations, a delay or process shutdown of the LAW immobilization plants) until a significant volume of waste is removed from the DST inventory at the LAW plants.

- Results of the Reliability, Availability, and Maintainability (RAM) studies may conclude that significantly more spare parts (replacement pumps, etc.) are required. RAM analyses are in progress. When the analyses are completed, appropriate mitigating activities (such as ordering more spare parts) will be initiated.

- Safety issues may not be resolved in time to meet the schedule to transfer feed. Unforseen issues may lead to additional design requirements as the Authorization Basis is expanded to meet the retrieval and immobilized product storage mission. The BIO (FDH 1997) was implemented in September 1997 and was focused primarily on the safe storage of wastes within the tank farm system. Although the $\mathrm{BIO}$ does authorize retrieval from tank $\mathrm{C}-106$ to support the retrieval and immobilized storage mission, the remaining Authorization Basis changes necessary to support Phase $1 \mathrm{~B}$ have not been completed. The RTP process assumes that no new significant or unforseen issues arise that cause significant addition to project work scope or significant delays in startup of the feed delivery systems. 
- Unplanned radiological exposures may occur during removal of existing equipment from the tanks or transfer systems or installation of new components or system. As low as reasonably achievable planning and design approach, combined with the lessons learned from projects W-151, W-030, and W-320 construction and operation will minimize exposure to acceptable levels. A key component of the planned approach is "mock up" training at the "cold test" facility which allows practicing the activities in normal and simulated casualty situations.

Additionally, the existing facilities will be surveyed to determine radiological conditions before the start of construction. This information will be used during the design and construction planning process to maintain as low as reasonably achievable principles.

Transfer lines may become plugged, resulting in delays of waste feed delivery to the private contractors. Risk mitigation consists of laboratory sample testing to verify actual waste properties, computer modeling to predict unwanted or unexpected chemical reactions during dilution or transfer, the ability to dilute during transfer, and the inclusion of instruments in the transfer system that will monitor system performance. A control valve has been included to allow the development of a slurry-specific pump performance curve during an in-tank recirculation mode before sending the waste into the transfer system. This will allow the monitoring of pump performance (based on curves developed for the actual slurry) during transfer to assist in the identification of upset conditions. In addition, the TWRS Project is participating in a Technology Demonstration Initiative led by the Savannah River Site to demonstrate commercial line unplugging technology in underground radioactive waste transfer lines.

- Analytical results (sample analyses) may not be available in time to meet schedules. Laboratory analysis turnaround times will be reevaluated. As necessary, procedures, processes, and instrumentation will be improved to provide additional certainty that feed delivery times can be met.

- If the results of mixer pump tests are unsatisfactory, selection and testing of an - alternate technology may be required, resulting in increased costs and schedule delays. Tests are planned at the vendor's facilities. Additional tests will be performed at Hanford in conjunction with the W-151 Project.

- The schedule for Canister Storage Building operations may conflict with TWRS activities to modify and utilize the Canister Storage Building for IHLW storage. It is recommended that DOE consider acceleration of required modifications to the Canister Storage Building. If the construction of the Canister Storage Building slips beyond the commitment point for TWRS, other storage options may need to be evaluated. 


\subsection{PHASE 1 FINANCIAL ANALYSES}

A detailed analysis of the overall costs to prepare for and perform the PHMC team portion of Phase 1B was completed. This analysis is discussed in detail in HNF-2017 (Wells 1998), financial analysis of Phase 1B. In general, the updated TWRS cost baseline for the period FY 1998 through FY 2011 is $\$ 5.4$ billion or $\$ 458$ million above (less than $10 \%$ ) the current target baseline. The Phase 1B Retrieval and Disposal portion of the $\$ 5.4$ billion is $\$ 2.4$ billion. The risk analysis suggests an execution probability of $80 \%$ at this value. The $\$ 458$ million in growth consists of approximately $\$ 210$ million in scope adjustments and an allowance for risk of $\$ 248$ million to increase program execution probability from $50 \%$ to $80 \%$. Some near term noncritical path adjustments of $\$ 5$ million in FY 1998 and $\$ 10$ million of additional funds in FY 1999 are required for the TWRS workscope to ensure retrieval critical path activities are fully funded.

Risk assessment opportunities have been identified which could partially offset the $\$ 458$ million growth and the known risks. These include the impacts of Fluor Daniel Hanford (FDH) sponsored reductions in site indirect and benefits program costs of $\$ 140$ million ( $\$ 10$ million in FY 1999) and realization of Enterprise Resource Planning (ERP) system related efficiencies of $\$ 60$ million.

This analysis was performed with the enabling assumptions described in the documents supporting this RTP evaluation. Significant changes or delays could affect the technical program requirements and this financial analysis.

\subsection{PHASE 1 SUMMARY AND CONCLUSIONS}

An overall systems approach has been applied to develop action plans to support the retrieval and immobilization waste storage and disposal mission. The systems approach included defining the mission requirements and evaluating the readiness of the PHMC team to support initiation of waste processing by the private contractors in June 2002 and to receive immobilized waste shortly thereafter. The Phase $1 \mathrm{~B}$ feed delivery requirements from the private contractor requests for proposal were reviewed. Transfer piping routes were mapped out, existing systems were evaluated, and upgrade requirements were defined. Technical basis reviews were completed for each step in the Level 1 Logics (FDH 1998) to define work scope in greater detail, understand cost estimates, and analyze technical and financial bases. TWRS personnel training, qualifications, management systems, and procedures were reviewed and shown to be in place and ready to support Phase 1B. Key assumptions and risks that could negatively impact mission success were evaluated and appropriate actions were planned and scheduled. 
The review concluded that the systems and infrastructure required to support the mission are known. Required systems are either in place or plans have been developed to ensure they. exist when needed. The review showed that since October 1996, a robust system engineering approach to establishing integrated Technical Baselines, WBSs, tank farm organizational structures and configurations, work scope, and costs has become a part of the TWRS culture. An analysis of programmatic, management, and technical activities necessary to declare RTP indicates that the system, personnel, and hardware will be on line and ready to support the private contractors.

\subsection{PHASE 2 PROCESSING RATE ANALYSIS AND RECOMMENDATIONS}

Approximately 50,000 MT of sodium will remain to be retrieved and immobilized in the full-scale plants built and operated in Phase 2. The Phase 2 functional requirements were derived from the Tri Party Agreement milestones (Ecology et al. 1996), the TWRS Environmental Impact Statement (DOE and Ecology 1996), preliminary DOE planning assumptions (see Table 13), and anticipated tank waste status at the end of Phase 1B. These functional requirements form the initial conditions for optimizing feed delivery rates, private contractor processing rates, and operations activities at the tank farms.

Table 13. Tri-Party Agreement Milestones.

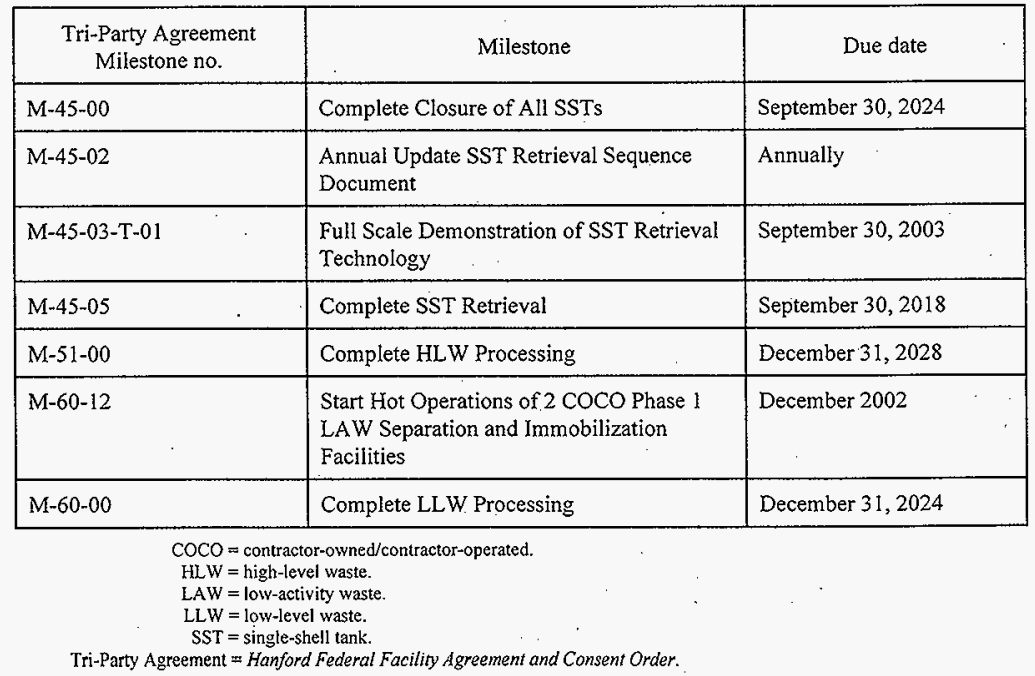


HNF-2021 Rev 1

\subsection{PHASE 2 FEED DELIVERY RATE REQUIREMENTS}

Tri-Party Agreement milestones (Ecology et al. 1996) and the Environmental Impact Statement (DOE and Ecology 1996) target retrieval of the wastes from all SSTs by late 2018 and completion of waste processing for LAW by late 2024 and HLW streams by 2028 , respectively. Estimated annual SST retrieval sequencing and tank retrieval schedules consider Phase 1 implementation of DST space limitations and logistics of the tank farm transfer systems (existing and new construction). The considerations are documented in the TWRS Operations and Utilization Plan (Kirkbride et al. 1997) and indicate that the earliest that SST retrieval can be completed is late 2020; however, the associated waste immobilization will be completed before the M-60 and M-51 milestone dates (Ecology et al. 1996). The Tri-Party Agreement establishes a goal of 99 percent retrieval of the waste from each SST.

\subsection{FEED DELIVERY ANALYSIS}

Figure 19 illustrates the Phase $1 \mathrm{~B}$ and Phase 2 processing rates. The Phase 1 program planning basis assumes that each private contractor would process $2 \mathrm{MT}$ of sodium per day. At these rates, the minimum order quantities would be processed by 2005 and the Phase $1 \mathrm{~B}$ maximum order quantity will be completed by approximately 2009. Assuming that $\mathrm{DOE}$ extends the operation of the Phase 1 facilities, SST wastes will be retrieved to DSTs for staging in anticipation of Phase 2. Once Phase $1 \mathrm{~B}$ feed is processed, the base case enters into a post Phase 1 evaluation phase in parallel with completion of construction of production scale facilities. Given DST space limitations, this base case would result in a 3-year period in which only SSTs with a small inventory could be retrieved. This may maintain the number rate of retrievals required by the Tri-Party Agreement (Ecology et al. 1996), but does not significantly reduce the volume of waste stored in SSTs. At the end of Phase 1B in 2009, 32 million gallons of waste $(-38,000 \mathrm{MT} \mathrm{Na})$ will remain in the SSTs (before washing or caustic addition).

A simplified global analysis was used to develop recommendations that could be used to improve Phase 2. This global analysis will be refined to include tank sequencing, space limitations, and processing considerations. The base case Phase 2 processing rate (Figure 17) assumptions require each Phase 2 private contractor to scale up their LAW processing capability to $13 \mathrm{MT}$ sodium per day ( $86 \mathrm{MT}$ glass).

To match this processing capacity, retrieval rates will have to be scaled up significantly. Based on prior sluicing experience, each sluicing unit can reliably sluice approximately 1,900 gallons of wastes ( $2.3 \mathrm{MT}$ sodium) from a tank per day. During the sluicing process total volumes are increased by a factor of approximately 3.3 for every gallon sluiced. Thus the total volume to be treated will increase to $\sim 115$ million gallons as a result of the retrieval process. 
Figure 19. Phase $1 \mathrm{~B}$ and Phase 2 Low-Activity Waste Processing Rates.

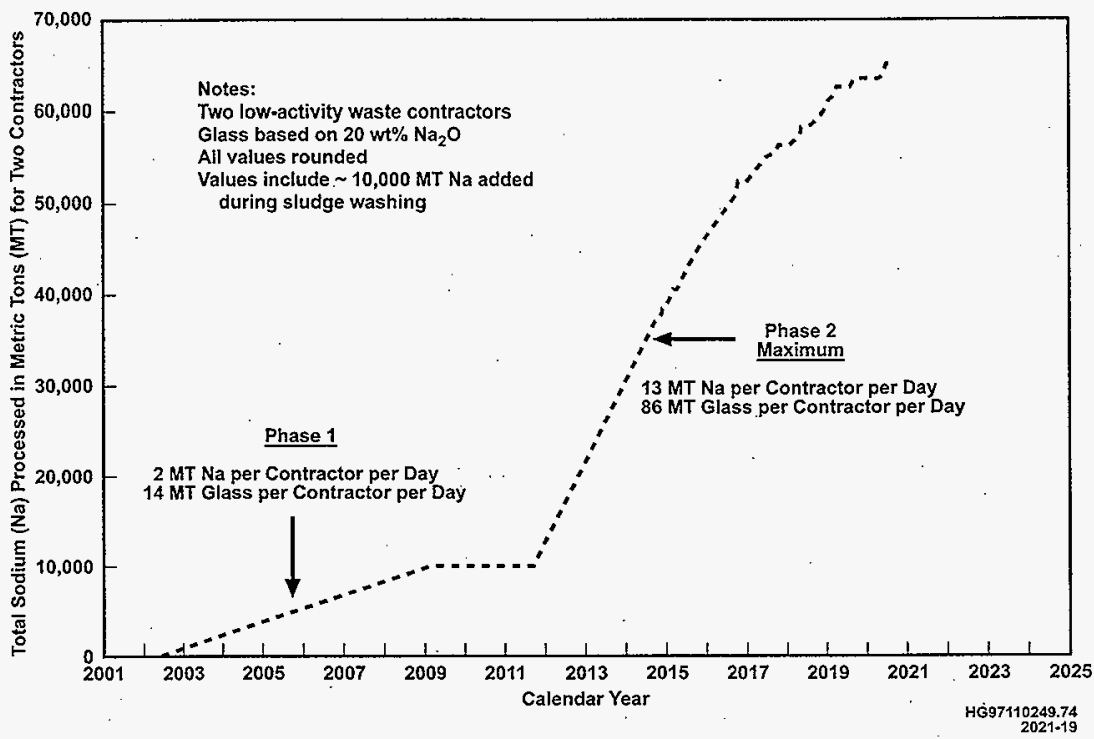

Therefore, to match the Phase 2 processing rates of $26 \mathrm{MT}$ sodium per day (13 MT per contractor) during the first three years; 21,500 gallons of waste will have to sluiced, requiring 11 tanks to be sluiced simultaneously. Table 14 presents the results of several studies comparing number of retrieval systems, SST retrieval completion, and maximum number of retrieval systems.

Preparation for sluicing in an SST farm is a major activity involving installation of new sluicing hardware, monitoring equipment, transfer lines, and utilities. Tank sluicing will require careful control and monitoring to ensure that the process is conducted safely.

The physical layout of the tank farm systems, assumptions about the amount of new construction required for retrieval and transfer facilities, and the anticipated complexity of field sluicing operations lead to the conclusion that it would be extremely difficult to sluice more than one tank simultaneously in one tank farm quadrant. One exception is $T$ Farm complex ( $T$, TX, TY), which contains 40 tanks and is farther from the existing infrastructure. Because new retrieval annexes will need to be built, along with additional transfer lines, it appears that two tanks in operation could be sustained in the $T$ Farm complex. The retrieval and transfer infrastructure will be distributed in the four major quadrants that make up the tank farm system 
Table 14. Number of Concurrent Retrieval Systems.

\begin{tabular}{|l|c|c|}
\hline \multicolumn{1}{|c|}{ Information source } & SST retrieval completion & $\begin{array}{c}\text { Peak SST retrieval systems in } \\
\text { operation }\end{array}$ \\
\hline $\begin{array}{l}\text { 1996 SST Initial Retrieval Sequence } \\
\text { (Penwell et al. 1996) }\end{array}$ & 2020 & 16 \\
\hline $\begin{array}{l}\text { 1997 TWRS Operation and Utilization } \\
\text { Plan (Kirkbride et al. 1997) }\end{array}$ & 2020 & 10 \\
\hline $\begin{array}{l}\text { Average Retrieval Rate Base } \\
\text { Calculation }\end{array}$ & 2020 & 11 \\
\hline
\end{tabular}

Kirkbride, R. A., G. K. Allen, P. J. Certa, A. F. Manuel, R. M. Orme, L. W. Shelton, E. J. Slaathaug, R. S. Wittman, and G. T.

MacLean, and D. L. Penwell (SESC), 1997, Tank Waste Remediation System Operation and Utilization Plan, HNF-SD-WM-SP-012, Rev. 0, Volumes I and II, prepared by Numatec Hanford Corporation for Fluor Daniel Hanford, Inc., Richland, Washington.

Penwell, D. L.; C. E. Grenard, and R. S. Wittman, 1996, Initial Retrieval Sequence and Blending Strategy, WHC-SD-WM-RPT-229, Rev. 0, Westinghouse Hanford Company, Richland, Washington. SST $=$ single-shell tank.

TWRS = Tank Waste Remediation System.

(Northeast, Southeast, Northwest, and Southwest; see Figure 20). Assuming that two tanks are being sluiced simultaneously in the T Farm complex (Northwest quadrant), it is likely that only one tank in each remaining quadrant could be operated during the same time frame without creating extensive operations resource loading and command and control concerns. Therefore, it is recommended that the maximum Phase 2 tank retrieval operations be limited to a maximum of five tanks simultaneously (two tanks in the Northwest quadrant, one tank in each remaining quadrant).

\subsection{MELTER CAPACITY SCALE-UP COMPARISON WITH COMMERCIAL INDUSTRY}

The baseline Phase 2 processing rates require a major increase in vitrification plant capacity. This scale up may not be achievable based on reasonable extensions of existing technology and recent nuclear vitrification plant experiences.

The largest remote radioactive melter in the DOE complex is 2.4 MT per day of glass product at the Defense Waste Processing Facility at Savannah River. Joule-heated or cold-wall induction melters used at United States and European facilities can be designed for larger capacities ( 5 to $10 \mathrm{MT}$ per day), but are not likely to achieve the rates required for LAW processing (approximately $86 \mathrm{MT}$ per contractor per day) in Phase 2 . Commercial glass plant capacities are much higher, but are not able to be directly applied because of differences in melter design, feed consistency, and remote operation (due to radioactivity) considerations. Multiple melter lines with the production-scale facilities or multiple facilities will be required to meet the current Phase 2 production rate assumptions. 
Figure 20. Tank Farm System Retrieval and Transfer Infrastructure.

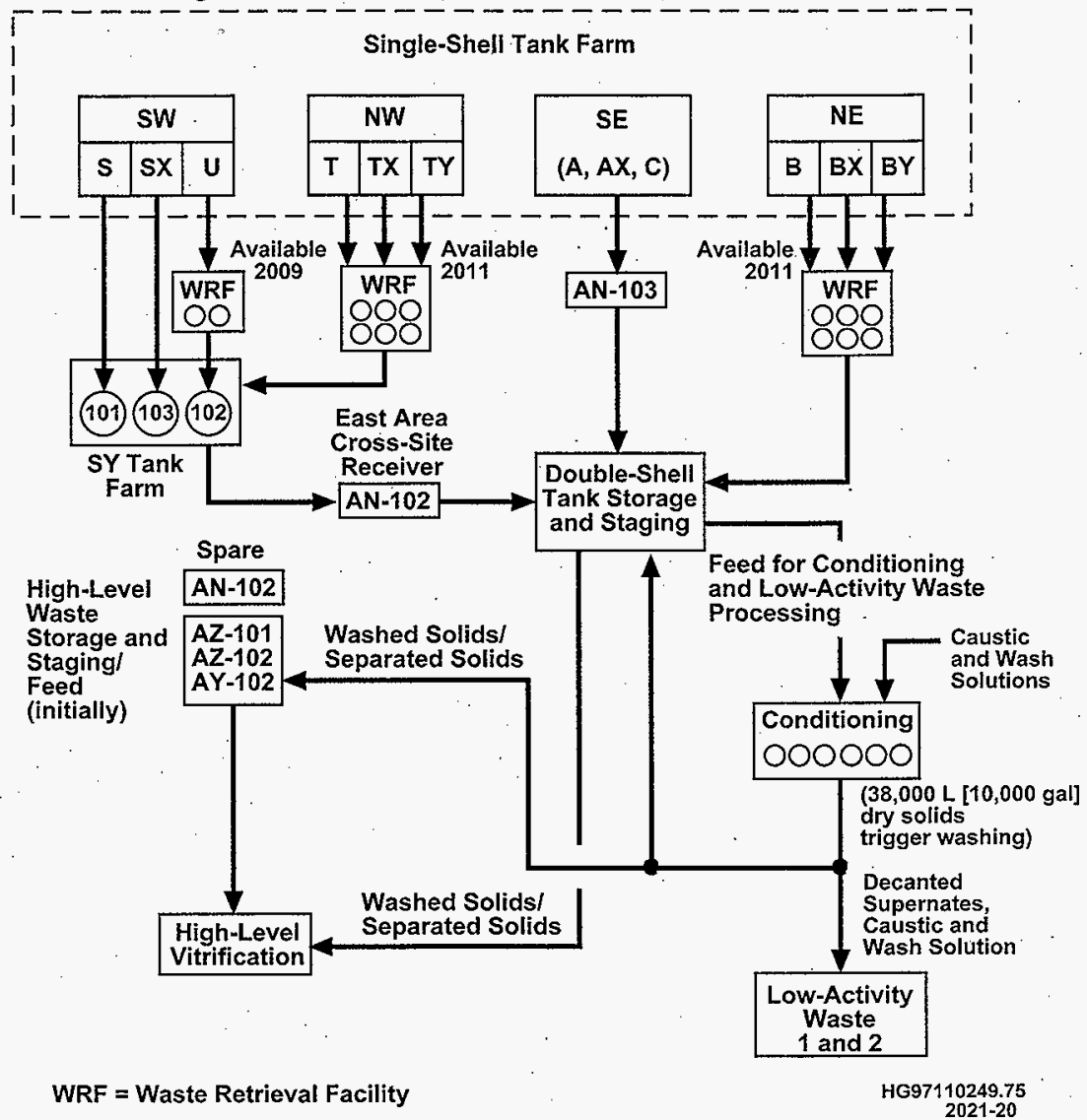

In general, scale up of remotely operated and maintained radioactive melters to the capacities required to support the current Phase 2 planning assumptions appears unlikely without a technology breakthrough. Scale up of the radioactive glass melters will likely be limited to around $10 \mathrm{MT}$ glass per day per melter line. Two LAW plants with three melter lines each could each produce about $40 \mathrm{MT}$ glass per day, which appears to be a reasonable planning assumption at this time. 


\subsection{STRATEGY OPTIMIZATION}

The top-level information discussed previously suggests a number of improvements that could be evaluated to accelerate the removal of waste from the SSTs, reduce the complexity and scale of the retrieval mission, and reduce the scale up required to meet the full-scale production mission requirements.

An early increase in the feed rate for the Phase 1 facilities (after minimum order quantities have been processed), coupled with extension of the operation of the Phase 1 facilities could have a significant positive effect. This extension would accelerate the rate of waste retrieval from SSTs, reduce the scale up required dramatically, and improve the overall feasibility of completing the entire mission.

Figure 21 shows a case that dramatically enhances the capability to complete Phase 2 on schedule. In this case, the Phase 1 private contractors are allowed to ramp up to their maximum production capacity as soon as the minimum feed quantities of envelope $\mathrm{A}, \mathrm{B}$, and $\mathrm{C}$ are demonstrated. The operation of these expanded Phase 1 facilities is extended to 2011 , followed by replacement with full-scale production facilities, or upgrades to the Phase 1 facilities that meet the mission requirements. Table 15 compares the existing base case to this improved example. The improved case would more than double the waste processed by 2011 .

While detailed modeling and analysis along with design and capacity information from the Phase 1 private contractors will be necessary to optimize the scenario, there are indications that a much more feasible scenario for the Phase 2 plan can be developed and shouid be pursued.

\subsection{RECOMMENDATIONS TO ACCELERATE THE REMOVAL OF WASTE FROM SINGLE-SHELL TANKS}

Consider relaxation of the feed envelopes and certification requirements as soon as the minimum demonstration order quantities of envelopes $\mathrm{A}, \mathrm{B}$, and $\mathrm{C}$ are completed. This would allow the PHMC team to deliver waste feed at rates greater than 2 MT Na per contractor per day, and should allow the private contractors to process waste faster and more efficiently. The demonstration requirements of the privatization strategy would be met, while faster processing of waste during Phase 1B will free up space and allow more SST retrieval to occur before construction of the full-scale production facilities in Phase 2.

Phase 2 feasibility could be further increased by accelerating the Phase 2 start date to coincide with the completion of Phase $1 B$ maximum order feed processing $(\sim 2009)$. This would accelerate the start of Phase 2 processing by nearly three years and would also decrease the scale up required to go from demonstration to full-scale production while still maintaining the planned retrieval end date of 2020 . 
Figure 21. Example Mission Improvements - Low-Activity Waste Processing.

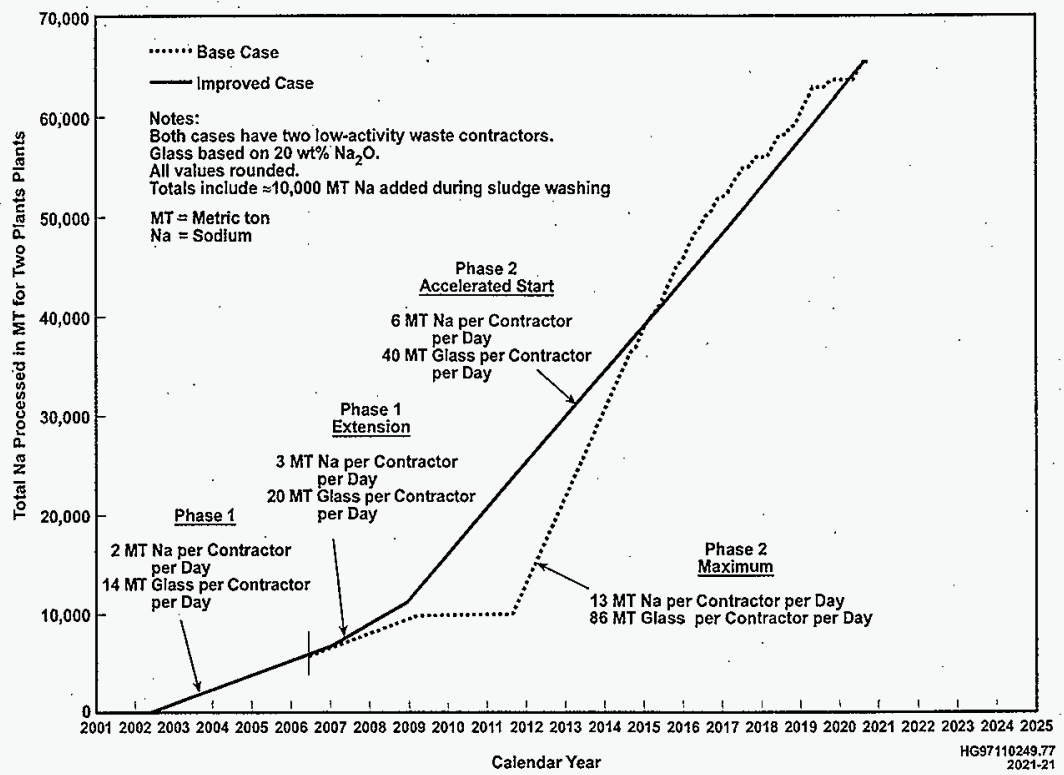

Table 15. Comparison of Tank Waste Remediation System Planning Baseline and Example Mission Improvements Case.

\begin{tabular}{|l|c|c|}
\hline & TWRS planning baseline & $\begin{array}{c}\text { Example case-mission } \\
\text { improvements }\end{array}$ \\
\hline SST retrieval completion & 2020 & 2020 \\
\hline $\begin{array}{l}\text { Maximum retrieval systems in } \\
\text { operation }\end{array}$ & 11 & 5 \\
\hline $\begin{array}{l}\text { Maximum Phase 2 melter rate (MT } \\
\text { glass/day for each private } \\
\text { contractor) }\end{array}$ & $86 \mathrm{MT} /$ day* & $40 \mathrm{MT} /$ day \\
\hline $\begin{array}{l}\text { Waste processed by 2011 } \\
\text { (MT sodium) }\end{array}$ & $10,000 \mathrm{MT}$ & $21,000 \mathrm{MT}$ \\
\hline
\end{tabular}
Phase 2.

*Average rate over Phase 2 is approximately $60 \mathrm{MT}$ per contractor per day, but $86 \mathrm{MT}$ per contractor per day will be reguired early in MT = metric ton. SST $=$ single-shell tank. TWRS $=$ Tank Waste Remediation System. 
Size the Phase 2 full-scale production facilities (or capacity upgrades to the Phase 1 facilities) to process the remaining SST waste at a constant rate, starting in 2009 and finishing as early as practical. It may even be possible to expand the Phase 1 private contractor facilities and thus reduce Phase 2 costs. Current analysis indicates that processing could be completed by 2024, with SST retrieval completed by 2020. The net effect, if implemented, would be to reduce the simultaneous operation of tank retrieval systems to a reasonable number (as low as 5), and to reduce the scale up required from $100 \mathrm{MT}$ of glass per contractor per day to around $40 \mathrm{MT}$ of glass per day, while effectively doubling waste processed by 2011 .

Although additional work is necessary to optimize the mission design, the work done to date clearly indicates significant enhancements are possible (and should be considered). Design information and processing capabilities proposed by the private contractors should be inputted into the Hanford Tank Waste Operation Simulator model and detailed analyses completed to further optimize the overall mission.

\subsection{REFERENCES}

Act

Occupational Safety and Health Act of 1970,29 USC 651 et seq.

\section{Database}

HSTD, n.d., Hanford Site Technical Baseline Database, database maintained by Lockheed Martin Hanford Corporation for Fluor Daniel Hanford, Inc., Richland, Washington.

\section{DOE Orders}

DOE Order 425.1, Startup and Restart of Nuclear Facilities, U.S. Department of Energy, Washington, D.C.

DOE Order 5480.20A, Personnel Selection, Qualification, and Training at DOE Nuclear Facilities, U.S. Department of Energy, Washington, D.C.

\section{Federal Register}

62 FR 8693, 1997, "Record of Decision for the Tank Waste Remediation System, Hanford Site, Richland, WA," Federal Register, Vol. 62, pp. 8693-8704 (February 26). 


\section{Logic Diagrams}

FDH, 1998, Logic Diagrams, prepared by Lockheed Martin Hanford Corporation for Fluor

Daniel Hanford, Inc., Richland, Washington.

- H-2-823148, TWRS Retrieval Level 1 Logic Immobilized Waste (ILAW)

- H-2-829149, TWRS Retrieval Level 1 Logic Immobilized Waste (IHLW)

- H-2-829150, TWRS Retrieval Level I Logic Infrastructure Phase 1 Privatization Support

- $\quad$ H-2-892151, TWRS Retrieval Level I Logic Waste Feed Delivery LAW Ist Feed Batches Tank 24I-AN-105

- H-2-829152, TWRS Retrieval Level 1 Logic Waste Feed Delivery LAW 2nd Feed Batches Tank 24I-AN-104

- H-2-829153, TWRS Retrieval Level 1 Logic Waste Feed Delivery LAW 3rd Feed Batches Tank 241-AW-101

- H-2-829154, TWRS Retrieval Level 1 Logic Waste Feed Delivery LAW 4th Feed Batches Tank 241-AN-103

- H-2-829155, TWRS Retrieval Level 1 Logic Waste Feed Delivery LAW 5th Feed Batches Tanks 241-AP-101 \& 241-AW-104

- H-2-829156, TWRS Retrieval Level 1 Logic Waste Feed Delivery LAW 6th Feed Batches Tank 241-AY-101

- H-2-829157, TWRS Retrieval Level 1 Logic Waste Feed Delivery LAW 7th \& 8th Feed Batches Tank 241-AN-107

- H-2-829158, TWRS Retrieval Level 1 Logic Waste Feed Delivery LAW 9th Feed Batches Tank 24I-AN-102

- H-2-829159, TWRS Retrieval Level 1 Logic Waste Feed Delivery LAW 10th Feed Batches Tank 241-AN-106

- H-2-829160, TWRS Retrieval Level 1 Logic Waste Feed Delivery LAW 11th Feed Batches Tank 24I-SY-101

- H-2-829161, TWRS Retrieval Level 1 Logic Waste Feed Delivery LAW 12th Feed Batches Tank 24I-SY-103

- H-2-829162, TWRS Retrieval Level 1 Logic Waste Feed Delivery HLW 1st \& 2nd Feed Batches First Tank, 241-AZ-101

- H-2-829163, TWRS Retrieval Level 1 Logic Waste Feed Delivery HLW 3rd \& 4th Feed Batches Second Tank, 241-AZ-102

- H-2-829164, TWRS Retrieval Level 1 Logic Waste Feed Delivery HLW 5th - 9th Feed Batches Third Tank, 241-AY-102

- H-2-829165, TWRS Retrieval Level 1 Logic Waste Feed Delivery HLW 10th - 12th Feed Batches Fourth Tank, 24I-C-104

- H-2-829166, TWRS Level O Logic (2 Sheets) 
HNF-2021 Rev 1

\section{Documents}

Acree, C. D., Jr., 1998, Tank Waste Remediation System Mission Analysis Report, HNF-SD-WM-MAR-008, Rev. 3, prepared by Lockheed Martin Hanford Corporation for Fluor Daniel Hanford, Inc., Richland, Washington.

Baldwin, J. H., T. J. McLaughlin, R. D. Potter; and R. L. Treat, 1998, Tank Waste Remediation System Retrieval and Disposal Mission Key Enabling Assumptions, HNF-1945, Rev. 0, prepared by Lockheed Martin Hanford Corporation for Fluor Daniel Hanford, Inc., Richland, Washington.

Borneman, L. E., 1998, Tank Waste Remediation System Environmental Program Plan, HNF-1773, Rev. 0, Fluor Daniel Hanford, Inc., Richland, Washington.

Brown, N. R. , 1996, "LLW Product Waste Loading Assumptions for the TWRS Process Flowsheet," Internal Memo to R. M. Orme, Department of Energy, Richland, Washington.

DNFSB, 1997, "Integrated Safety Management," Technical Repórt Number 16, Defense Nuclear Facilities Safety Board, Washington, D. C.

DOE and Ecology, 1996, Tank Waste Remediation System, Hanford Site, Richland, Washington, Final Environmental Impact Statement, DOE/EIS-0189, U.S. Department of Energy and Washington State Department of Ecology, Washington, D.C.

Ecology, 1997, "Department of Energy's Ability to Declare Readiness to Proceed for Privatization," Letter to John Wagoner from Mike Wilson, dated November 19, 1997 U.S. Department of Ecology, Olympia Washington.

Ecology, EPA, and DOE, 1996, Hanford Federal Facility Agreement and Consent Order, 2 vols., Washington State Department of Ecology, U.S. Environmental Protection Agency, and U.S. Department of Energy, Olympia, Washington.

FDH, 1997, Tank Waste Remediation System Basis for Interim Operation, FNF-SD-WM-BIO-001, Rev. 0, Fluor Daniel Hanford, Inc., Richland, Washington.

Freeman, D. V., 1998, Tank Waste Remediation System Program Plan, HNF-1883, Rev. 1, prepared by Lockheed Martin Hanford Corporation for Fluor Daniel Hanford, Inc., Richland, Washington.

Hall, C. A., 1998, Tank Waste Remediation System Retrieval and Disposal Mission Readiness-to-Proceed Guidance and Requirements to Deliverables Crosswalk, HNF-2020, Rev. 0, prepared by Lockheed Martin Hanford Corporation for Fluor Daniel Hanford, Inc., Richland, Washington. 
Jordan, K. N., and H. L. Boston, 1998, Tank Waste Remediation System Retrieval and Disposal Mission Readiness-to-Proceed Memorandum, HNF-2019, Rev. 1, prepared by Lockheed Martin Hanford Corporation for Fluor Daniel Hanford, Inc., Richland, Washington.

INPO, 1996, Institute of Nuclear Power Operations 1996 Annual Report, Institute of Nuclear Power Operations, Atlanta, Georgia.

Kirkbride, R. A., G. K. Allen, P. J. Certa, A. F. Manuel, R. M. Orme, L. W. Shelton, E. J. Slaathaug, R. S. Wittman, and G. T. MacLean, and D. L. Penwell (SESC), 1997, Tank Waste Remediation System Operation and Utilization Plan, HNF-SD-WM-SP-012, Rev. 0, Volumes I and II, prepared by Numatec Hanford Corporation for Fluor Daniel Hanford, Inc., Richland, Washington.

Lenseigne, D. L., 1997, Tank Waste Remediation System Fiscal Year 1998 Multi-Year Work Plan WBS 1.1, HNF-SP-1230, Rev. 0, prepared by Lockheed Martin Hanford Corporation for Fluor Daniel Hanford, Inc., Richland, Washington.

LMHC, 1997, TWRS Administration, Fluor Daniel Hanford, Inc., Richland, Washington.

Mickle, G. D., 1995, Tank Farm Health and Safety Plan, WHC-SD.WM-HSP-002, Rev. 2, Westinghouse Hanford Company, Richland, Washington.

Peck, L.G., 1998, Tank Waste Remediation System Systems Engineering Management Plan, HNF-SD-WM-SEMP-002, Rev. 1, prepared by Lockheed Martin Hanford Corporation for Fluor Daniel Hanford, Inc., Richland, Washington.

Penwell, D. L., C. E. Grenard, and R. S. Wittman, 1996, Initial Retrieval Sequence and blending Strategy, WHC-SD-WM-RPT-299, Rev. 0, Westinghouse Hanford Company.

Popielarczyk, R. S., 1996, TWRS Safety Management Plan, WHC-SD-WM-PLN-114, Rev. 1, Westinghouse Hanford Company, Richland, Washington.

Rifaey, S. H., 1998, Tank Waste Remediation System Engineering Plan, HNF-1947, Rev. 0, prepared by Lockheed Martin Hanford Corporation for Fluor Daniel Hanford, Inc., Richland, Washington.

RL, 1996a, Lockheed Martin Advanced́d Environmental Systems Privatization Contract, DE-AC06-96RL13309, U.S. Department of Energy, Richland Operations Office, Richland, Washington.

RL, 1996b, Project Hanford Management Contract (PHMC), DE-AC06-96RL13200, U.S. Department of Energy, Richland Operations Office, Richland, Washington. 
Schaus, P. S., 1998, Tank Waste Remediation System Retrieval and Disposal Mission Readiness-to-Proceed Responses to Internal Independent Assessment, HNF-2018, Rev. 0, prepared by Lockheed Martin Hanford Corporation for Fluor Daniel Hanford, Inc., Richland, Washington.

Strode, J. N., and V. C. Boyles, 1997, Operational Waste Volume Projection, HNF-SD-WM-ER-029, Rev. 23, prepared by Lockheed Martin Hanford Corporation for Fluor Daniel Hanford, Inc., Richland, Washington. (Table 5)

Swita, W. R., M. R. Lewis, and M. J. O’Neill, 1998, Tank Waste Remediation System Retrieval and Disposal Mission Initial Updated Baseline Summary, HNF-1946, Rev. 1, prepared by Lockheed Martin Hanford Corporation for Fluor Daniel Hanford, Inc., Richland, Washington.

Taylor, W. J., 1997, Contract Number DE-AC06-96RL13200, Tank Waste Remediation System (TWRS) Privatization - Hanford Contractors Readiness to Proceed (letter 97-WDD-129 to H. J. Hatch, Fluor Daniel Hanford, Inc., August 8), U.S. Department of Energy, Richland Operations Office, Richland, Washington.

Vann, J. M., E. R. Hamm, and R. D. Crisp, 1998, Tank Waste Remediation System Configuration Management Plan, HNF-1900, Rev. 0, prepared by Lockheed Martin Hanford Corporation for Fluor Daniel Hanford, Inc., Richland, Washington.

Wells, M. W., 1998, Tank Waste Remediation System Retrieval and Disposal Mission Phase I Financial Analysis, HNF-2017, Rev. 1, prepared by Lockheed Martin Hanford Corporation for Fluor Daniel Hanford, Inc., Richland, Washington.

Wojtasek, R. D., 1997, Readiness-To-Proceed Plan for M\&I Contractor Workscope in Support of TWRS Phase $1 B$ Privatization, HNF-1241, prepared by Lockheed Martin Hanford Corporation for Fluor Daniel Hanford, Inc., Richland, Washington.

Zimmerman, B. D., 1998, Tank Waste Remediation System Retrieval and Disposal Mission Risk List, Rev. 0, prepared by Lockheed Martin Hanford Corporation for Fluor Daniel Hanford, Inc., Richland, Washington. 


\section{DISTRIBUTION SHEET}

\begin{tabular}{|c|c|c|c|c|c|}
\hline \multirow{2}{*}{$\begin{array}{l}\text { To } \\
\text { Document Control Services }\end{array}$} & \multirow{2}{*}{\multicolumn{3}{|c|}{$\begin{array}{l}\text { From } \\
\text { TWRS Configuration Management }\end{array}$}} & \multicolumn{2}{|c|}{ Page I of 1} \\
\hline & & & & \multicolumn{2}{|c|}{ Date January 3. 1998} \\
\hline \multicolumn{4}{|l|}{ Project Title/work Order } & \multicolumn{2}{|l|}{ EDT No. } \\
\hline \multicolumn{4}{|c|}{ Tank Waste Remediation Systems (HNF-2021) } & \multicolumn{2}{|c|}{ ECN No. 644555} \\
\hline Namé & MSIN & $\begin{array}{c}\text { Text } \\
\text { With A1? } \\
\text { Attach. }\end{array}$ & $\begin{array}{l}\text { Text } \\
\text { Only }\end{array}$ & $\begin{array}{l}\text { Attach./ } \\
\text { Appendix } \\
\text { Only }\end{array}$ & $\begin{array}{l}\text { EOT/ECN } \\
\text { Only }\end{array}$ \\
\hline
\end{tabular}

J.N. ATibert

H.L. Boston

M.P. Delozier

M.D. Ebben

0. A. Halvorson

J.0. Honeyman

K.N. Jordan

R.A. Kirkbride

S.C. Klimper

M.R. Lewis

D.M. McDaniel

R.J. Murkowski

M.A. Payne

M.L. Peterman

R.W. Powell .

R.E, Raymond

S.H. Rifaey

B. Root

P.S. Schaus

S.E. Seeman

S.J. Simon

W.R. Swita

R.L. Treat

J.M. Vann

J.H. Wicks Jr

R.D. Wojtasek
$52-48 \quad x$

G3-21 2 copies

R2-58 $\quad X$

H7 $-07 \quad X$

G3-21 . $X$

G3-21 $X$

G3-21

H5-27

H6-25

H5- 03

H7-06

H6-37

R2-58

H7- 06

H5- 03

R2-38

R1-56

G3-21

H5- 03

H6-35

H7-06

H5- 03

H5- 03

H6-37

47-07

G3-21 $x$
$x$
$x$
$x$

$x$

$x$

$x$

3 copies

3 copies

2 copies

$x$

$x$

$x$

$x$

$x$

- $x$

$x$

$x$

$x$

2 copies

$X$

$x$

3 copies 